NBER WORKING PAPER SERIES

\title{
SOURCES OF REAL EXCHANGE RATE \\ FLUCTUATIONS: HOW IMPORTANT \\ ARE NOMINAL SHOCKS?
}

\author{
Richard Clarida \\ Jordi Gali
}

\author{
Working Paper No. 4658
NATIONAL BUREAU OF ECONOMIC RESEARCH 1050 Massachusetts Avenue
Cambridge, MA 02138
February 1994

This paper was prepared for the Carnegie-Rochester Conference on Public Policy held at Camegie-Mellon University in November 1993. This paper is part of NBER's research program in Intemational Finance and Macroeconomics. Any opinions expressed are those of the authors and not those of the National Bureau of Economic Research. 


\title{
SOURCES OF REAL EXCHANGE RATE \\ FLUCTUATIONS: HOW IMPORTANT \\ ARE NOMINAL SHOCKS?
}

\begin{abstract}
This paper investigates empirically and attempts to identify the sources of real exchange rate fluctuations since the collapse of Bretton Woods. The paper's first two sections survey and extend earlier, non-structural empirical work on this subject by Campbell and Clarida (1987), Meese and Rogoff (1988), and Cumby and Huizinga (1990). The paper's main contribution is to build and estimate a three equation open macro model in the spirit of Dornbusch (1976) and Obstfeld (1985) and to identify the model's structural shocks - to demand, supply, and money using the approach pioneered by Blanchard and Quah (1989). For two of the four countries we study, Germany and Japan, our structural estimates imply that monetary shocks, to money supply as well as to the demand for real money balances, explain a substantial amount of the variance of real exchange rates relative to the dollar. We find that demand shocks, to national saving and investment, explain the majority of the variance in real exchange rate fluctuations, while supply shocks explain very little. The model's estimated short run dynamics are strikingly consistent with the predictions of the simple textbook Mundell-Fleming model.
\end{abstract}

Richard Clarida

Department of Economics

International Affairs Building

Room 1020

Columbia University

New York, NY 10027

and NBER

\author{
Jondi Gali \\ Department of Economics \\ International Affairs Building \\ Columbia University \\ New York, NY 10027
}




\section{SOURCES OF REAL EXCHANGE RATE FLUCTUATIONS:}

HOW IMPORTANT ARE NOMINAL SHOCKS?

$$
\text { by }
$$

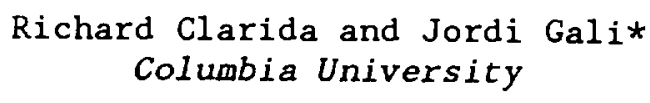

\section{Introduction}

This paper investigates and attempts to identify the sources of real exchange rate fluctuations since the collapse of the Bretton Woods system of fixed exchange rates in the early 1970s. In an influential paper, Mussa (1986) argued that sluggish price adjustment must play a central role in explaining the short run movements in real and nominal exchange rates. He based this conclusion on the indisputable fact that the volatility of real exchange rates since the collapse of Bretton Woods has closely tracked the volatility of nominal exchange rates, and that the variance of real exchange rates since the collapse of fixed exchange rates has been 8 to 80 times higher than during Bretton Woods.

Stockman (1987) pointed out that, according to the equilibrium approach to exchange rates developed in his and other papers, the behavior of real exchange rates since the collapse of Bretton Woods could reflect not the importance of sluggish price level adjustment, but rather the influence of real shocks with large permanent components. The empirical findings that, since the collapse of Bretton Woods, real exchange rates appear to possess a unit root and that most of the variance of changes in real exchange rates is attributed to permanent shocks (Huizinga (1987)), and that little of the variance of real exchange rate changes can be accounted for by real interest rate differentials (Campbell and Clarida (1987); Meese and Rogoff (1988)) have, taken together, tended to cast 
doubt on the relevance of the basic "sticky price" open macro model (Dornbusch (1976)) for explaining real exchange rates. Meese and Rogoff (1988) conclude:

Our evidence provides no support whatsoever for the view that a model [that emphasizes the interaction of sticky prices and monetary disturbances] can explain the major swings in the real exchange rate. The strongest prediction of those models - that real interest differentials will be highly correlated with real exchange rate movements - simply does not appear in the data. (Meese and Rogoff (1988), p. 940)

Any model of the real exchange rate that incorporates monetary neutrality in the long run implies that the level of the real exchange rate, at least in the long run, is invariant to shocks in money supply and the demand for real money balances. It follows that, if money is to have an influence on real exchange rates, the influence must be felt in the short run. Empirically, this means that an upper bound on the contribution of monetary shocks to the variance of real exchange rate changes is given by the variance of the change in the transitory component in real exchange rates. This is an upper bound because real shocks to national absorption, fiscal shocks, and supply, productivity shocks can also have transitory effects on the real exchange rate.

In the next section of this paper, we revisit the real interest rate - real exchange rate connection. We show how the approach introduced by Campbell and Clarida (1987) and Meese and Rogoff (1988) and studied recently by Baxter (1992) can be generalized to allow for a much wider class of stochastic processes for the real interest differential than is 
required by these previous papers. Notwithstanding this generalization, we find, as did Campbell and Clarida (1987) and Meese and Rogoff (1988) that the transitory component in dollar real exchange rates implied by the time series on real interest differentials accounts for only a trivial fraction of the variance in the log change in real exchange rates.

In the paper's third section we estimate the transitory component in real exchange rates using a multivariate version of the Beveridge-Nelson (1981) decomposition. In addition to lagged real exchange rate changes, the VAR information set used to forecast future real exchange rate changes includes lagged inflation differentials and lagged changes in US output relative to foreign output. We include lagged inflation differentials in the VAR because, as demonstrated by Cumby and Huizinga (1990), lagged inflation helps to forecast subsequent changes in bilateral real exchange rates. Lagged inflation differentials are also likely to be correlated with nominal shocks in the US relative to the foreign country under study. We include lagged $\log$ changes in the ratio of US to foreign output because the evidence of a unit root in real exchange rates suggests that real shocks - to supply as well as to demand for national outputs such as fiscal shocks (Meltzer (1993)) - must play a role in understanding the behavior of real exchange rates since 1973. While the Beveridge-Nelson decompositions based upon these trivariate VARs are not structural, we investigate and estimate later in the paper a structural open macro model that employs these very VARs.

We find, as did Cumby and Huizinga (1990) who computed Beveridge Nelson decompositions using a smaller system that included only the lagged inflation differentials, that there is a substantial transitory component 
in the dollar-DM and dollar-yen real exchange rates. In particular, we show that the variance of the change in the BN transitory component is 70 percent of the variance of the change in the dollar-DM real exchange rate, and 59 percent of the variance of the change in the dollar-yen real exchange rate. We also show that lagged inflation differentials Granger cause real exchange rate changes in these two countries. We contrast the transitory component in real exchange rates recovered froil a univariate BN decomposition with the component recovered from our multivartate system.

In section four of the paper, we present a three equation open macro model that can be used to interpret the trivariate VARs estimated in section three of the paper. This model, which is a stochastic version of the two country, rational expectations open macro model developed by Obstfeld (1985), exhibits the standard Mundell-Fleming-Dornbusch results in the "short run" when prices adjust sluggishly to money, supply, and demand shocks, but it also embodies the "longer run" properties that characterize macroeconomic equilibrium in the open economy once prices adjust fully to all shocks. Throughout this paper, we shall refer interchangeably to "nominal" shocks and "monetary" shocks. Our theoretical model, and our empirical strategy, allows for shocks to relative national money supplies and relative national demands for real money balances. The combined impact of these disturbances is identified as a monetary, or nominal, shock by our approach. We employ the long run properties of this model - properties that are shared with many other open macro models including the cash-in-advance Arrow-Debreu models developed by Lucas (1982) and others - to obtain restrictions that can be used to identify three structural shocks that drive the system: shocks to "money", 
shocks to "demand", and shocks to "supply". Identification is achieved using the approach pioneered by Blanchard and Quah (1989), employed by Shapiro and Watson (1988), Gali (1992), Bayoumi and Eichengreen (1992), and critiqued by Evans and Reichlin (1993). An important advantage of the Blanchard-Quah approach to identification is that we do not have to take a stand on the dynamics or the contemporaneous exclusion of any structural shock from any particular equation. Rather, we use only the longer run restrictions implied by our model - and many other open macro models - to identify the structural dynamics from the data.

Section five presents the paper's key empirical results. For two of the four countries we investigate, Japan and Germany, our structural VAR estimates imply that nominal shocks explain a substantial amount of the variance in dollar-DM and dollar-yen real exchange rates. In particular, we find that more than 41 percent of the unconditional variance of the change in the dollar-DM real exchange rate, and more than 35 percent of the variance of the change in the dollar-yen real exchange rate are attributed to nominal shocks. For the other two countries in our study, Britain and Canada, there is much less evidence that nominal shocks are important for real exchange rate fluctuations. We also devote extensive efforts to determine whether or not the money, demand, and supply shocks our empirical models recover "look like" such shocks are supposed to look. We do this by decomposing the "real time" history of each real exchange rate into the history of the implied monetary, demand, and supply influences that, according to our estimates, generated the realized path of the real exchange rate. We also generate impulse response functions to the three structural shocks and compare those responses with those implied 
by our versicr of the Mundell-Fleming-Obstfeld model presented in Section four. One contribution of this paper is to demonstrate that in all four countries, the short run dynamic responses of relative national outputs, prices, and the real exchange rate to money and demand shocks are consistent with the predictions of a stochastic, rational expectations version of the textbook Mundell-Fleming model.

Section six of the paper compares our findings with those reported recently in the literature and provides some concluding remarks. 


\section{Real Interest Rates and the Transitory Component in Real Exchange Rates}

Over the past decade, a number of papers have exploited the relationship between real interest differentials and real exchange rates implied by interest parity to make inferences about the transitory component embedded in real exchange rates (Frankel $(1979 ; 1985)$, Loopesko and Shafer (1983), Sachs (1985), Campbell and Clarida (1987), Meese and Rogoff (1988), Baxter (1992), and Edison and Pauls (1993)). Letting $\mathrm{rr}_{\mathrm{t}}$ denote the short term ex ante real interest differential in favor of the home country:

$$
r r_{t}=\left(i_{t}^{h}-E_{t} \pi_{t+1}^{h}\right)-\left(i_{t}^{f}-E_{t} \pi_{t+1}^{f}\right)
$$

uncovered interest parity implies:

$$
r r_{t}=E_{t} \Delta q_{t+1}
$$

where $q_{t}=s_{t}+p_{t}^{f}-p_{t}^{h}$ is the $\log$ of the real exchange rate and $E_{t}$ is the linear projection operator. Equation (2) can be solved forward to obtain:

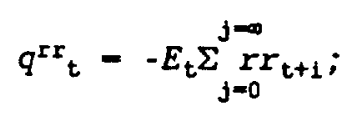

where $\mathrm{q}^{r r}{ }_{t}$ is the difference between the current level of $q_{t}$, the real exchange rate, and $\hat{q}_{t}-1 i m_{j+\infty} E_{t} q_{t+j}$, the expected long run level of the real exchange rate;

$$
q^{r r}=q_{t}-1 i m_{j+\infty} E_{t} q_{t+j}
$$

Thus when $\mathrm{q}^{\mathrm{rr}} \mathrm{t}$ is negative and the dollar is transitorily overvalued relative to the level of long run real exchange rate, the magnitude of this overvaluation is given by the sum of ex ante real interest 
differcntials in favor of the dollar. The expected sum of ex ante real interest differentials is unobservable. However, letting

$$
r_{t+1}=\left(i_{t}^{h}-\pi_{t+1}^{h}\right)-\left(i_{t}^{f}-\pi_{t+1}^{f}\right)
$$

denote the ex post real interest rate differential and using the fact that $r r_{t}=E_{t} r_{t+1}$, we can use the law of iterated expectations to express $q^{r r}$ in terms of ex post real differentials:

$$
q^{r r}=-E_{t} \sum_{j=1}^{j=\infty} r_{t+j}
$$

Projecting both sides of (5) on an informationion set $x_{t}$ we obtain:

$$
E\left(q^{r r}\left\{i x_{t}\right)=-E\left(\sum_{j=1}^{j=\infty} r_{t+j} \mid x_{t}\right) .\right.
$$

The right hand side of (6) can be obtained by summing the forecasts derived from an estimated VAR model for $x_{t}$ that includes the ex post real interest rate differential. According to (6), the estimate each period of the sum of real interest differentials derived in this fashion is, in population, equal to the projection of the transitory component of the real exchange rate $q^{r x}$ on the information set $x_{t}$ that would be obtained under interest parity if $q^{r r_{t}}$ were in fact observable.

We estimate $E\left(q^{r x}, j x_{t}\right)$, the transitory divergence between the real exchange rate and the expected long run real exchange rate implied by interest parity, using a bivariate VAR in $\left[\Delta q_{t}, r_{t}\right]$ to forecast each period the sum of real interest differentials. We use non-overlapping data on 3 month ex post real interest differentials and the 3 month $\log$ difference in the real exchange rate for Germany, Japan, Canada, and Britain over the floating exchange rate period 1973:3-1992:1. Since the interest rate data for Japan begin in 1975:3, our estimates of $q^{r x}$ for Japan cover the period 
1975:3 - 1992:1. Both real interest differentials and the change in the real exchange rate are constructed using CPI indexes of national price levels. Each VAR contain sa constant and 4 lags of $\Delta q$ and $r$.

Charts 1 through 4 present the results of this exercise. The center panel of each chart depicts the time path of $-\mathrm{q}^{\mathrm{rr}}{ }_{\mathrm{t}}$ implied by the interest parity relationship (6) and the estimated bivariate VAR. The top panel in each chart presents, using a solid line, the actual time path of the level of the real exchange rate $q_{t}$ and presents, using a broken 1 ine, the time path of the estimated long run real exchange rate that is defined by (4) and that can be recovered using the estimates of $E\left(q^{r r} \mid x_{t}\right)$.

Chart 1 presents the results for Germany. As can be seen from the top panel of Chart 1 , the floating rate years have been marked by three period of substantial, sustained swings in the real value of the dollar relative to the DM. In the first period, 1977 through 1979, the dollar depreciated by 20 percent in real terms against the DM in tandem with an acceleration in US inflation and a loss in confidence in US monetary policy. In the second period, 1980 through 1984, the real value of the dollar appreciated by more than 50 percent against the DM. This appreciation occurred in conjunction with shift to a disinflationary US monetary policy and change in the US fiscal stance that resulted in a pronounced widening in the US budget deficit and a decline in national saving. In the third period, 1985 through 1987, the dollar depreciated by 40 percent in real terms against the DM.

The center panel of Chart 1 presents the estimates of $-q^{r r_{t}}$, the transitory over or under valuation of the dollar relative to its long run level implied by the time series properties of ex post real interest 
differentials and interest rate parity. The estimates of $-q^{r r}$ implied by real interest differentials suggests a modest degree of overshooting in the dollar-DM real exchange rate in each of these three episodes. In particular, throughout the 1977 - 1979 period in which the dollar depreciated by 20 percent against the DM in real terms, expected future real interest differentials implied a 2 to 3 percent under valuation of the real dollar-DM exchange rate - and thus the expectation of a 2 to 3 percent appreciation of the dollar. Of course, that expectation was more than realized between 1980 and 1984 as the real value of the dollar appreciated by 50 percent or more against the DM. We note that consistently throughout 1982, 1983, and 1984, the time series of expected future real interest differentials implied that the dollar was overvalued by 3 to 5 percent relative to the DM in real terms during this appreciation and thus, that the dollar was expected ultimately to depreciate and "give back" 3 to 5 percent of the huge real appreciation of the early 1980s. Again, this expectation was more than realized between 1985 and 1987 when the real value of the dollar against the DM did in fact depreciate, but by 40 percent. As during the 1977 - 1979 real depreciation, expected future real interest differentials implied a 3 to 4 percent under valuation of the real dollar-DM exchange rate throughout 1986 and 1987, suggesting some modest amount of overshooting in the real dollar-DM exchange rate in the years following the Plaza Accord.

Chart 2 presents the results for Japan. As with Germany, we observe in retrospect three period of substantial, sustained swings in the real value of the dollar relative to the yen: a two year period, 1977 through 1978, of sustained dollar depreciation, followed by a six year period, 
1979 through 1984, in which the real dollar-yen exchange rate appreciated by 50 percent, followed by a three year interval in the which the exchange rate depreciated by 50 percent against the yen in real terms. The estimates of $-q^{\text {rr }}$ presented in the center panel of Chart 2 provide some modest indication of overshooting in the 1977-1978 and 1985-1987 periods of dollar-yen real depreciation, with the dollar estimated to be some 1 to 2 percent undervalued in 1977-1978 and 1985-1987. There is somewhat more evidence of overshooting during the years 1981-1984 in which the dollar was estimated to be 2 to 3 percent overvalued.

Chart 3 presents the UK results. Again, three intervals of substantial, sustained swings in the real value of the dollar relative to sterling are evident in the data. However, the estimates of $-\mathrm{q}^{\mathrm{rr}}$ presented in the center panel of Chart 3 provide little indication of overshooting in the 1977-1979 period of dollar-sterling real depreciation or in the 1980-1984 period of dollar-sterling real appreciation. However, the estimates do suggest that the dollar did overshoot by some 3 to 4 percent in 1986 and 1987.

Chart 4 presents the results for Canada. contrast with the other three countries the dollar actually appreciated against the Canadian dollar in real terms during 1977-1979, and continued this appreciation throughout most of period 1980-1985. Consistently, the time series of forecasted real interest differentials indicates that the dollar was overvalued during this appreciation and was expected to depreciate in real terms by some 2 to 3 percent. Beginning in 1986, the dollar did in fact begin a sustained real depreciation, overshooting the long run real exchange rate by some 3 percent. 
The top panel of Table 1 reports the ratio of the sample variance of $\Delta q^{r r}$ to the sample variance of $\Delta q_{t}$ for each of the four real exchange rates relative to the dollar. These results confirm impression conveyed by Charts 1 to 4: little of the variance of real exchange rate changes can be accounted for by changes in the expected sum of future real interest differentials. These findings generalize, but support, the conclusions of Campbell and Clarida (1987) and Meese and Rogoff (1988) who assumed that the expected sum of future real interest differentials is proportional to the current ex ante real interest differential $q^{r r_{t}}-\xi r r_{t}$. The center panel of Table 1 reports Granger causality tests for the bivariate VARs containing 4 lags of $\left[\Delta q_{t}, r_{t}\right]$ that are used to estimate $q^{r x}$, the transitory component in each real exchange rate relative to the dollar. As can be seen in the table, ex post real interest differentials are forecastable. For all four countries, lagged ex post real interest differentials help to forecast future real differentials and in two countries, lagged changes in real exchange rates Granger cause real interest differentials. By contrast, Table 1 shows that changes in real exchange rates are substantially less forecastable conditional on this information set containing lagged real exchange rate changes and lagged real interest differentials. Moreover, in no country do lagged real interest differentials Granger cause subsequent real exchange rate changes.

According to interest parity $E_{t} r_{t+1}=E_{t} \Delta q_{t+1}$. Projecting both sides on the VAR information set $x_{t}-\left[\Delta q_{t}, \ldots, \Delta q_{t-3}, r_{t}, \ldots, r_{t-3}\right]$ we see that:

$$
E\left(r_{\mathrm{t}+1} \mid \mathrm{x}_{\mathrm{t}}\right)=E\left(\Delta q_{\mathrm{t}+1} \mid \mathrm{x}_{\mathrm{t}}\right)
$$


Thus, the interest parity hypothesis that is used to estimate $\mathrm{q}^{\mathrm{rr}}{ }_{t}$ implies a set of cross-equations on the VAR, namely, that coefficients in each VAR projection equation be identical. The results obtained from testing these restrictions for each country are presented in the lower panel of Table 1. As can be seen from the table, in three of the four cases, these restrictions on the VAR forecasting equation can be soundly rejected at the 2 percent significance level. These restrictions cannot be rejected for the dollar-yen system, but this appears to be due to the fact that the real dollar-yen exchange rate is unforecastable in this bivariate system so that imposing the interest parity restrictions does not lead to a substantial deterioration of the log likelihood. Of course, there are scores of papers employing alternative, perhaps more powerful tests that have investigated and rejected the uncovered interest parity hypothesis (see Hodrick (1988) for a survey). The point we wish to make here is simply that, the interest parity restrictions that are relevant for estimating the transitory component in real exchange rates from observations on real interest differentials are apparently also violated in the data.

To get a sense of the magnitude of the divergence between $E\left(q^{r r} \mid x_{t}\right)$ and $E\left(\Sigma_{j=1, \infty} \Delta q_{t+j} \mid x_{t}\right)$, we plot in the bottom panel of Charts $1-4$ the latter series based upon the estimated bivariate VAR for each country. To interpret these plots, we note that if interest parity held - or if we imposed the interest parity cross-equation restrictions when forecasting real exchange rate changes and real interest differentials from the VARs the line that plots $-E\left(q_{t}^{r r} \mid x_{t}\right)$ in the center panel and the line that plots $-E\left(\Sigma_{j=1, \infty} \Delta q_{t+j} \mid x_{t}\right)$ in the lower panel of each chart would coincide exactly. 
As is evident, this is far from the case. We conclude that, from the perspective of recovering estimates of the transitory component in real exchange rates, the departures from interest parity are substantial enough to warrant the consideration of alternative approaches. 


\section{Multivariate Beveridge-Nelson Decompositions}

While the results obtained by using forecasts of real interest rates to make inferences about the behavior of the transitory component in the real exchange rate are suggestive of some modest, persistent degree of divergence between current and long run real exchange rates, the dominant impression one derives from the Charts $1-4$ is the extent to which the time path of the long run real exchange rate mimics the time path of the actual real exchange rate. Over the past 20 years of floating exchange rates relative to the dollar, a number of authors (Roll (1979); Frenkel (1981); Adler and Lehman (1983); Cumby and Obstfeld (1985); GrilliKaminski(1991); Edison and Pauls (1993)) have presented empirical evidence that indicates that real exchange rates relative to the dollar possess a unit root. That is, real exchange rates are integrated of order $1, I(1)$, and are driven by permanent shocks.

A popular and intuitive way to decompose an $I(1)$ time series into a permanent and a trausitory component is due to Beveridge and Nelson (1981). A Beveridge - Nelson decomposition of the real exchange rate $q_{t}$ implies that the transitory departure of the real exchange rate from its expected long run equilibrium is given by:

$$
q_{\mathrm{t}}^{\mathrm{BN}}=-E_{\mathrm{t}}\left(\sum_{\mathrm{j}=1}^{\mathrm{j}-\Delta} \Delta q_{\mathrm{t}+\mathrm{j}} \mid \Delta q_{\mathrm{t}}, \Delta q_{\mathrm{t}-1}, \ldots .\right)
$$

The BN decomposition defines the permanent, or expected long run, real exchange rate $\hat{q}_{t}^{\mathrm{BN}}$, as :

$$
\hat{q}_{\mathrm{t}}^{\mathrm{BN}}=q_{\mathrm{t}}+E_{\mathrm{t}} \Sigma_{\mathrm{j}=1}^{\mathrm{j}-\infty} q_{\mathrm{t}+\mathrm{j}}
$$


Combining (8) and (9) we see that $q^{B N}+\hat{q}_{t}^{B N}=q_{t}$. Beveridge and Nelson (1981) prove that $\hat{\mathrm{q}}^{\mathrm{BN}}{ }_{t}$ is a random walk, while $\mathrm{q}^{\mathrm{BN}} \mathrm{t}$ is stationary since $\mathrm{q}_{t}$ is $I(1)$.

Huizinga (1987) employed the Beveridge-Nelson decomposition to investigate the importance of the permanent component in real exchange rates relative to the dollar since the 1973 advent of floating. Using the history of changes in the real exchange rate itself as his information set to estimate the Beveridge-Nelson transitory component defined by equation (8), Huizinga found evidence that, while fluctuations in the permanent component of the real exchange rate account for most of the volatility of observed changes in real exchange rates, actual real exchange rates relative to the dollar did appear to overshoot persistently and revert rather gradually to the to the long run equilibrium real exchange rate defined by the Beveridge-Nelson permanent component.

Huizinga's (1987) univariate decomposition of the real exchange rate followed the lead of Beveridge and Nelson in their original work. Recently, several authors have uncovered some interesting implications of multivarlate generalizations of the Beveridge-Nelson decomposition (Evans (1989), Cochrane (1990), and King, Plosser, Stock, and Watson (1991), and Evans and Reichlin (1993)). One finding, due to Evans and Reichlin (1993), is that, if the multivariate information set includes variables that Granger cause subsequent changes in the real exchange rate, the variance of the transitory component relative to the Beveridge-Nelson permanent component derived from such a multivariate system must strictly exceed the ratio of the transitory component to the permanent component derived from a univariate information set. 
In this section, we present the results of trivariate BeveridgeNelson decompositions of the log real exchange rate of the dollar relative to the yen, DM, sterling, and the Canadian dollar based upon VAR forecasts of the change in the real exchange rate. The information set includes not only lagged changes in the log real exchange rate, but also lagged inflation differentials between the US and the foreign country, $\pi_{t-j}$, and lagged changes in the $\log$ ratio of US to foreign real GDP, $\Delta y_{t-j}$. The data are quarterly and span the floating exchange rate period 1973:3 - 1992:4.1 We include lagged inflation differentials in the information set because, as demonstrated by Cumby and Huizinga (1990), lagged inflation helps to forecast subsequent changes in bilateral real exchange rates. Cumby and Huizinga (1990) studied a bivariate Beveridge-Nelson decomposition of the log real exchange in a system that included lagged inflation differentials. The results of this section of our paper obviously build on their work. We go beyond Cumby and Huizinga (1990) by including a "real" as well as a "nominal" variable in the information set, by explicitly comparing the multivariate with the corresponding univariate decompositions, and by demonstrating the importance of Granger causality in accounting for the differences between the decompositions. Lagged inflation differentials are also likely to be correlated with nominal shocks in the US relative to the foreign country under study. We include lagged $\log$ changes in US to foreign output because the evidence of a unit root in real exchange rates, in conjunction with the theoretical model we derive below, suggests that real shocks - to the supply as well as to demand for national outputs - must play a role in understanding the behavior of real exchange rates since 1973 (Campbell and Clarida (1987); 
Stockman (1987)). While the Beveridge-Nelson decompositions based upon these trivariate VARs are not structural, we investigate and estimate later in the paper a structural open macro model that employs these very VARs.

Charts 5 through 8 present the results of these decompositions. The bottom panel in each chart depicts, using a solid line, the time path of $q^{B N}{ }_{t}$ which may be interpreted as magnitude of the over or under valuation of the real dollar exchange rate relative to $\hat{q}^{\mathrm{BN}}{ }_{t}$, the Beveridge-Nelson permanent component. The bottom panel in each chart also depicts, using a dashed line, the time path of $-q^{B N U}{ }_{t}$, the over or under valuation of the dollar real exchange rate obtained from a univariate Beveridge-Nelson decomposition. The top panel in each chart presents, using a solid line, the actual time path of the level of the real exchange rate $q_{t}$ and presents, using a dashed line, the time path of the estimated long run real exchange $\hat{q}_{t}^{\mathrm{BN}}$ derived from the trivariate system.

As can be seen in the bottom panel of Chart 5 , the estimates of $q^{B N}$ based upon the trivariate Beveridge-Nelson decomposition reveal sustained periods of substantial overshooting in the dollar-DM real exchange rate. In particular, throughout the 1978 - 1979 period of real dollar depreciation against the DM, the dollar was undervalued by some 20 to 30 percent relative to the long run real exchange rate defined by $\hat{q}_{t}^{\mathrm{BN}}$. By contrast, throughout the years 1983, 1984, and 1985 of "benign neglect" during which the dollar surged, the real value of the dollar was consistently overvalued by 10 to 14 percent, implying the expectation that 10 to 14 percent of the dollar's real appreciation during the early 1980 s would be given back through eventual real depreciation. (CHART 5 HERE) 
The contrast between the time series $q^{B N}$ and $q^{B N U}$ for the dollar-DM real exchange rate is striking for two reasons. First, the transitory component in the real exchange rate implied by the multivariate decomposition is substantially larger and more volatile than is transitory component implied by the univariate decomposition, a fact evident from Chart 5 that we shall quantify shortly. Second, $\mathrm{q}^{\mathrm{BN}} \mathrm{t}$ is persistently of the opposite sign to $\mathrm{q}^{\mathrm{BNU}}{ }_{t}$. This means that, regardless of the differences in magnitude, in periods such 1977 - 1979 when the dollar was depreciating and in which the trivariate Beveridge-Nelson decomposition implies that the dollar was undervalued and expected to appreciate in real terms, the univariate decomposition implies that the dollar was overvalued and expected to depreciate further. Moreover, in periods such 1982 - 1985 when the dollar was appreciating and in which the trivariate BeveridgeNelson decomposition implies that the dollar was overvalued and expected to depreciate in real terms, $\mathrm{q}^{\mathrm{BNU}} \mathrm{t}$ implies that the dollar was undervalued and expected to appreciate further. Evans and Reichlin (1993) document a similar difference between univariate and multivariate Beveridge-Nelson decompositions of US real GDP. They demonstrate that $\operatorname{cov}\left(\Delta \mathrm{q}_{t}, \mathrm{q}^{\mathrm{BN}} \mathrm{t}\right)$ - $\Sigma_{j=1, \infty} \operatorname{cov}\left(\Delta q_{t}, \Delta q_{t-j}\right)$. Thus the sign of the covariance between the change in the real exchange rate and the level of the Beveridge-Nelson transitory component depends upon the autocovariance of $\Delta q_{t}$. Evans and Reichlin (1993) conclude that the contrast between the univariate and multivariate estimates of the transitory component depends upon differences in estimating the autocovariance using a univariate as opposed to a multivariate information set. 
Chart 6 presents the Beveridge-Nelson decomposition results for the dollar-yen real exchange rate. Again, the estimates of $q^{B N}$ based upon the trivariate Beveridge-Nelson decomposition reveal sustained periods of substantial overshooting in the dollar-yen real exchange rate, both in absolute terms and in comparison with the estimates for $q_{t}^{B N U}$. We note that in 1976 and $1977, q^{B N}$ indicated that the dollar was substantially overvalued relative to the yen and was expected ultimately to depreciate by some 30 percent in real terms against the yen. A real depreciation of this magnitude did in fact occur in 1978 and 1979. Indeed, the BeveridgeNelson decomposition indicated that the real value of the dollar depreciated beyond its expected long run level sometime in early 1979, and was thereafter undervalued throughout the rest of 1979,1980 and 1981 , years in which the dollar actually did appreciate in real terms against the yen. Overshooting is also evident during the later years, 1982 1985, of the dollar's Reagan-Volcker appreciation.

Charts 7 and 8 present the real exchange rate decomposition results for the US-UK and the US-Canada. These decompositions differ both qualitatively and quantitatively from those just presented for the US and Germany and the US and Japan. As is evident from Charts 7 and 8 , and as will be confirmed shortly, relative to the dollar, ltei sterling and Canadian dollar exchange rates appear to possess rather small, and not particularly persistent, transitory components. In other words, conditional on the trivariate information set studied in this section, very little of the change in either the dollar-sterling or the dollar-Canadian dollar real exchange rate is forecastable. Moreover, for these two real exchange rates relative to the dollar, the behavior of the 
transitory components derived from the trivariate systems does not differ substantially from the transitory component implied by the univariate decompositions .

The top panel of Table 2 presents sample estimates of the ratio of the variance of the change in the Beveridge-Nelson transitory component in the real exchange rate to the variance of the actual change in the real exchange rate.

These results confirm the impressions conveyed by Charts $5-8$. Based upon the Beveridge-Nelson decompositions derived from the trivariate systems, the variance of the change in the transitory component of the dollar-DM and dollar-yen real exchange rates is estimated to account for a quite substantial fraction of the actual change in these real exchange rates. Whether or not one views this as a "substantial" transitory component depends of course on one's priors. Until the mid 1980s, there was something of a consensus among researchers that most movements in real exchange rates represented transitory fluctuations around a slowly changing, if not constant, equilibrium real exchange rate. Since the papers by Campbell and Clarida (1987), Huizinga (1987), Stockman (1987), Meese and Rogoff (1988), and Grilli and Kaminski (1991), the weight of the evidence suggests that most movements in real exchange rates represent permanent shifts in real exchange rates. However, Grilli and Kaminski (1991) point out that real exchange rate "facts" can be quite regime specific, and that post-1973 empirical regularities, including the importance of permanent shocks, may not generalize to other floating exchange rate periods. By contrast, transitory predictable changes in the real dollar-sterling and Canadian dollar exchange rates appear, based upon the sample variances, to be much 
less important in accounting for changes in these real exchange rates. The top panel of Table 2 also reinforces the point, evident in the Charts, that the Beveridge-Nelson decomposition of the real exchange rate into permanent and transitory components depends upon the information set. For the dollar-DM and the dollar-yen real exchange rates, the ratio of the variance of the transitory component to the change in the real exchange rate based upon the trivariate VAR is four times larger than is the ratio based upon a univariate autoregressive model for real exchange rate changes. For the dollar-sterling and especially the US-Canadian dollar real exchange rates, there is much less differences between the variance ratios calculated from the univariate and multivariate information sets. The bottom panel of Table 2 presents some summary statistics for the estimated trivariate VARs. For the dollar-DM and dollar-yen real exchange rates, we see that lagged inflation differentials Granger cause subsequent real exchange rate changes. Cumby and Huizinga (1990) document that lagged inflation differentials help to forecast real exchange rate changes, but they do not report on Granger causality. Evans and Lothian (1993) do document Granger causality from lagged inflation, but not inflation differentials, to real exchange rate changes. For the dollar-sterling and Canadian dollar real exchange rates, there is no evidence that lagged inflation differentials, or for that matter lagged output growth differentials, have incremental predictive content for subsequent real exchange rate changes. These findings are relevant for interpreting Chart $5-8$ and the variance ratios reported in the top panel of Table 2. As mentioned earlier, if the multivariate information set includes variables that Granger cause subsequent changes in the real exchange rate, the 


\begin{abstract}
variance of the Beveridge-Nelson transitory component relative to the Beveridge-Nelson permanent component derived from such a multivariate system must strictly exceed the ratio of the Beveridge-Nelson transitory component to the permanent component derived from a univariate information set. Thus, the finding of Granger causality for the dollar-DM and dollaryen systems, and the absence of Granger causality in the dollar-sterling and Canadian dollar systems, can account for the differences in variance ratios reported in Table 2 .
\end{abstract}




\section{A Stochastic Rational Expectations Open Macro Model}

We now present a stochastic version of the two country, rational expectations open macro model developed by Obstfeld (1985). The model also draws on papers by Dornbusch (1976), Branson (1979), Flood (1981), Mussa (1982), Buiter and Miller (1983), McCallum (1988), and Canzoneri and Henderson (1991). The model not only exhibits the standard MundellFleming-Dornbusch results in the "short-run" when prices adjust sluggishly to demand, money, and supply shocks, but it also embodies the "longer-run" properties that characterize macroeconomic equilibrium in the open economy once prices adjust fully to all shocks. ${ }^{2}$ All vartables except interest rates are in logs and represent home relative to foreign levels. For example, $y_{t}=y_{t}^{h}-y_{t}{ }^{\mathrm{h}}$ and $i_{t}=i_{t}^{h}-i_{t}{ }_{t}$.

IS Equation:

$$
y_{\mathrm{t}}^{\mathrm{d}}-d_{\mathrm{t}}+\eta\left(s_{\mathrm{t}}-p_{\mathrm{t}}\right)-\sigma\left(i_{\mathrm{t}}-E_{\mathrm{t}}\left(p_{\mathrm{t}+1}-p_{\mathrm{t}}\right)\right) .
$$

Price Setting Equation:

$$
p_{\mathrm{t}}=(1-\theta) E_{\mathrm{t}-1}{p_{\mathrm{t}}^{e}}^{\mathrm{e}}+\theta{p_{\mathrm{t}}^{\mathrm{e}}} .
$$

LM Equation:

$$
m^{s}-p_{t}=y_{t}-\lambda i_{t} .
$$

Interest Parity:

$$
i_{t}=E_{t}\left(s_{t+1}-s_{t}\right) .
$$

Equation (10) is an open economy IS equation in which the demand for home output relative to foreign output is increasing in the real exchange rate and a relative demand shock $d_{t}$ and is decreasing in the real interest differential in favor of the home country. We think of $d_{t}$ as capturing shocks to home absorption relative to foreign absorption such as fiscal shocks. Equation (11) is a version of the price setting equations that 
have been studied in open macro setting by Flood (1981), Mussa (1982), and others. According to (11), the price level in period $t$ is an average of the market clearing price expected in $t-1$ to prevail in $t, t-1 \mathrm{P}_{t}{ }_{t}$, and the price that would actually clear the output market in period $t, p_{t}{ }_{t}$. When $\theta=1$, prices are fully flexible and output is supply determined. When $\theta$ $=0$, prices are fixed and predetermined 1 period in advance. Equation (12) is a standard LM equation, while Equation (13) is a statement of interest parity. In the sequel we shall let the variable $m_{t}$ capture the influence of shocks to relative national money supplies as well as shocks to relative national demands for real money balances.

Before we solve the model, we need first to specify the stochastic processes that govern the relative supply of output $y^{s} t$, the relative demand shock $d_{t}$, and relative money $m_{t}$. In general, we would expect output supply, output demand, and money to be driven by both transitory as well as permanent shocks. For ease in obtaining an explicit, uncluttered solution to the stochastic sticky price equilibrium, we shall suppose that both $y_{t}^{s}$ and $m_{t}$ are simple random walks and thus that shocks to supply and money are solely permanent. However, it will be useful to allow for both a transitory as well as a permanent component in the relative demand shock $d_{t}$. In particular, we suppose that a fraction $\gamma$ of any shock to relative demand in period $t$ is expected to be reversed in $t+1$. Pulling these assumptions together we have:

$$
\begin{aligned}
& y^{s}=y_{t-1}^{s}+z_{t} ; \\
& d_{t}=d_{t-1}+\delta_{t}-\gamma \delta_{t-1} ; \\
& m_{t}=m_{t-1}+v_{t} .
\end{aligned}
$$




\section{Solving the Model}

To solve the model, we begin by deriving an expression for the real exchange rate $q_{t}^{e}$ that would prevail in a "flexible price" rational expectations equilibrium in which output is supply determined. Substituting the laws of motion for $y_{t}^{s}$ and $d_{t}$ into (10) and solving for $q^{a}{ }_{t}$, we obtain:

$$
q_{t}^{e}=\left(y_{t}^{s}-d_{t}\right) / \eta+(\eta(\eta+\sigma))^{-1} \sigma \gamma \delta_{t} .
$$

The "flexible price" real exchange rate depreciates in response to a supply disturbance and appreciates in response to a demand disturbance. We note that when $\gamma>0$, the expectation that the demand disturbance will be partially reversed in the future sets up the expectation of real depreciation and dampens the magnitude of the appreciation in the present.

We next derive an expression for the price level $\mathrm{p}^{{ }}{ }_{t}$ that would prevail in the "flexible price" rational expectations equilibrium. From (12) and the definition of the real exchange rate, the $p^{e}{ }_{t}$ must satisfy $(1+\lambda) P_{\mathrm{t}}^{\mathbf{e}}=\mathrm{m}_{\mathrm{t}}-y_{\mathrm{t}}^{\mathrm{s}}+\lambda\left(E_{\mathrm{t}} q_{\mathrm{t}+1}^{\mathbf{a}}-q_{\mathrm{t}}^{\mathrm{e}}\right)+\lambda E_{\mathrm{t}} P_{\mathrm{t}+1}^{\mathbf{e}}$. Using (14) and (15), we obtain:

$$
p_{t}^{e}=m_{t}-y_{t}^{3}+\lambda(1+\lambda)^{-1}(\eta+\sigma)^{-1} \gamma \delta_{t} .
$$

All three shocks influence the time path of the "flexible price" price level. The "flexible price" relative price level rises in proportion to the monetary shock, declines in proportion to the supply shock, and rises In response to the temporary component in the demand shock. A solely permanent relative demand shock pushes up the common world level of real and nominal interest rates in the flexible price equilibrium. Thus, given output supply and money, a permanent demand shock must drive up home and foreign prices in proportion, leaving $\mathrm{p}_{\mathrm{t}}{ }_{\mathrm{t}}$ unchanged. 
Collecting these expressions, we see that the evolution over time of the flexible price equilibrium can be represented by the following three equations:

$$
\begin{aligned}
& y_{t}^{e_{t}}=y_{t}^{s} ; \\
& q_{t}^{e_{t}}=\left(y_{t}^{s_{t}}-d_{t}\right) / \eta+(\eta(\eta+\sigma))^{-1} \sigma \gamma \delta_{t} ; \\
& p_{t}^{e_{t}}=m_{t}-y_{t}^{s}+\lambda(1+\lambda)^{-1}(\eta+\sigma)^{-1} \gamma \delta_{t} .
\end{aligned}
$$

In this flexible price equilibrium, the levels of relative output, $y^{e} t$, the real exchange rate, $q_{t}{ }_{t}$, and relative national price levels, $p_{t}{ }_{t}$ are driven by three shocks - to supply, $z_{t}$, demand $\delta_{t}$, and money, $v_{t}$. As can be seen by inspection of (17), the system is triangular in the flexible price equilibrium. Only supply shocks influence the level of relative national outputs in the flexible price equilibrium, while both supply and demand shocks influence the level of the real exchange rate. Finally, all three shocks - to money, supply, and demand - influence the ratio of home to foreign price levels in the flexible price equilibrium.

With this characterization of the system's flexible price equilibrium, we now solve for the actual open macro equilibrium in a world of sluggish price adjustment. Substituting (16) into the price setting rule (11), we see that $p_{t}$, the ratio of home to foreign price levels, evolves according to:

$$
p_{t}-p_{t}^{e}-(1-\theta)\left(v_{t}-z_{t}+\alpha \gamma \delta_{t}\right) ;
$$

where $\alpha \equiv \lambda(1+\lambda)^{-1}(\eta+\sigma)^{-1}$. In response to a positive money or demand shock, the price level rises but by less than does the flexible price $\mathrm{p}^{{ }} \mathrm{t}$. In response to a positive supply shock the price level $p_{t}$ falls but by less 
than does the flexible price $\mathrm{p}_{t}{ }_{t}$. The degree of "sluggishness" is indexed by $(1-\theta)$. When $\theta-1$, prices are fully flexible, and the actual price $p_{t}$ coincides with $\mathrm{p}_{\mathrm{t}}^{\bullet}$.

The expression for the real exchange rate $q_{t}$ under sluggish price adjustment can be obtained by substituting (10) and (13) into (12) and using (18) to represent the difference between actual and market clearing price levels. We obtain:

$$
q_{\mathrm{t}}=q_{\mathrm{t}}^{\bullet}+\nu(1-\theta)\left(v_{\mathrm{t}}-z_{\mathrm{t}}+\alpha \gamma \delta_{\mathrm{t}}\right)
$$

where $\nu=(1+\lambda)(\lambda+\sigma+\eta)^{-1}$. We see that when price adjustment is sluggish, shocks to money influence the real exchange rate, even though monetary shocks have no influence on the flexible price real exchange rate. This follows from the renowned Dornbusch (1976) overshooting result which is a property of our model when price adjustment is sluggish. The nominal exchange rate is given by $s_{t}-s_{t}^{0}+(1-\sigma-\eta)(\lambda+\sigma+\eta)^{-1} \times(1-$ $\theta)\left(v_{t}-z_{t}+\alpha \gamma \delta_{t}\right)$. Overshooting in response to monetary shocks will occur if $(1-\sigma-\eta)>0$. Interestingly, this condition implies the nominal exchange rate will undershoot relative to the flexible price equilibrium in response to real supply and demand shocks. We note that sluggish price adjustment implies that the real exchange rate undershoots relative to the flexible price real exchange rate in response to real supply or demand shocks.

Finally, we can use (19) and the IS equation to solve for the demand determined level of output in the "short run" when price adjustment is sluggish. We obtain:

$$
y_{t}=y_{t}^{s}+(\eta+\sigma) \nu(1-\theta)\left(v_{t}-z_{t}+\alpha \gamma \delta_{t}\right) .
$$


Sluggish price adjustment implies that not only supply, but also money and demand shocks, influence $y_{t}$ in the short run. A monetary shock boosts output in the short run with sluggish price adjustment, while home relative to foreign output rises in response to the temporary component in the demand shock.

In the stochastic open macro equilibrium represented by equations (18), (19), and (20), all three shocks - to money, supply, and demand influence contemporaneously the levels of all three of the system's variables - output, the real exchange rate, and prices. However, because output, the real exchange rate, and prices are expected to converge to their flexible price equilibrium levels, the system is triangular in the long run. Indeed, with the simple price setting rule we employ, the system is expected to converge to the flexible price equilibrium in a single period. Only supply shocks are expected to influence the long run level of relative output. Supply and demand shocks are expected to influence the long run level of the real exchange rate. And finally, both real supply shocks and nominal monetary shocks are expected to influence the long run level of prices at home and abroad. 3 While these restriction are intuitive and are easily and explicitly derived in our model, they should also hold in many other specifications of a stochastic open macro equilibrium, including those that arise in the cash-in-advance ArrowDebreu open macro models pioneered by Lucas (1982). Drawing upon the approach pioneered by Blanchard and Quah (1989), we will exploit these quite plausible long run restrictions in an effort to identify the influence of money, demand, and supply shocks on the behavior of real exchange rates over the past twenty years. ${ }^{4}$ 


\section{The Empirical Strategy}

Our theoretical model implies that $y_{t}, q_{t}$, and $p_{t}$ are nonstationary in levels but stationary in first differences.s Letting $\Delta x_{t} \equiv\left[\Delta y_{t}, \Delta q_{t}\right.$, $\left.\pi_{t}\right]^{\prime}$ denote the 3 by 1 vector of the system's 3 variables and $\epsilon_{t} \equiv\left\{z_{t}\right.$, $\left.\delta_{t}, v_{t}\right]^{\prime}$ denote the 3 by 1 vector of the system's 3 structural disturbances, we think of the data on $\Delta y_{t}, \Delta q_{t}$, and $\pi_{t}$ as being generated by the following structural moving average model:

$$
\Delta \mathrm{x}_{\mathrm{t}}=C_{0} \epsilon_{\mathrm{t}}+C_{1} \epsilon_{\mathrm{t}-1}+C_{2} \epsilon_{\mathrm{t}-2}+\ldots
$$

where $C_{0}$ is the 3 by 3 matrix that defines the contemporaneous structural relationship among the system's 3 variables. As discussed earlier, if our simple expository model actually generated the data, the structural moving average model - and the estimated reduced form - would be a vector MA(1). In general, we would expect and do find much richer dynamics in the data. An important advantage of the Blanchard-Quah approach to identification is that we do not have to take a stand on the dynamics. Rather, we use only the longer run restrictions implied by our model - and many other open macro models - to identify the structural $C_{i}$ matrices from the data.

When we estimate a VAR, we do not directly recover estimates of the structural moving average model. Rather, we estimate:

$$
\Delta x_{t}=u_{t}+R_{1} u_{t-1}+R_{2} u_{t-2}+\ldots .
$$

where $u_{t}$ is a vector reduced form disturbances. We assume that there exists a nonsingular matrix $S$ such that $u_{t}-S \epsilon_{t}$. Comparing (21) with (22) we see that: $C_{0}=S, C_{1}-R_{1} S, C_{2}-R_{2} S$, i.e. $C(L)-R(L) S$. Thus:

$$
u_{\mathrm{t}}-C_{0} \epsilon_{\mathrm{t}} \text {. }
$$

In addition to recovering estimates of the parameters that define the reduced form moving average representation (22), we also recover an 
estimate of the symmetric variance-covariance matrix of the of the reduced form disturbances:

$$
\Sigma=E u_{t} u^{\prime}{ }_{t}
$$

As is well known, the model (22) is underidentified: it is not possible to obtain estimates of $C_{0}$ and thus $\epsilon_{t}$ without addition restrictions. To see this suppose, as is common in the literature, that the structural shocks are mutually orthogonal and that each has unit variance (the latter requirement is without loss of generality). Then, from (23) and (24), we see that:

$$
C_{0} C_{0}=\Sigma
$$

This representts a system of 9 equations in only 6 unknowns, the 3 variances and 3 covariances that define $\Sigma$. Thus, 3 additional restrictions are needed to identify $C_{0}$ and to recover the times series of structural shocks $\epsilon_{t}$ as well as the structural system dynamics defined by $\mathrm{C}_{1}, \mathrm{C}_{2}, \ldots$.

\section{Identification According to Blanchard-Quah}

It will be recalled that our open macro model is triangular in the long run. That is, only supply shocks $z_{t}$ are expected to influence relative output levels in the long run, while both supply and demand shocks $d_{t}$ are expected to influence the real exchange rate in the long run. Shocks to money $v_{t}$ are expected to have no long run impact on either relative output levels or the real exchange rate. Using the notation of our structural moving average model these restrictions are easily 
represented. Letting $C(1)=C_{0}+C_{1}+C_{2}+\ldots$, the restriction that neither money $v_{t}$ nor demand $d_{t}$ shocks influence relative output levels in the long run requires that:

$$
C_{12}(1)=C_{13}(1)=0 \text {. }
$$

Similarly, the the restriction that money shocks $v_{t}$ do not influence the real exchange rate in the long run requires that:

$$
C_{23}(1)=0
$$

We will now show that these 3 additional "long run" restrictions, restrictions that are implied by our model as well as many other open macro models including simple real business cycle models, are sufficient to identify the structural matrix $C_{0}$, to recover the structural system dynamics defined by $C_{1}, C_{2}, \ldots$. as well as the time series of structural shocks $\epsilon_{\mathrm{t}}=\left[z_{\mathrm{t}}, \delta_{\mathrm{t}}, \mathrm{v}_{\mathrm{t}}\right]^{\prime}$ to supply, demand, and money.

Letting $R_{0}=I, R_{1}=C_{1} C_{0}^{-1}, R_{2}=C_{2} C_{0}^{-1}$, and so on, the reduced form moving average (22) that is estimated can be written:

$$
\Delta x_{\mathrm{t}}=R_{0} \mathrm{u}_{\mathrm{t}}+R_{1} \mathrm{u}_{\mathrm{t}-1}+R_{2} \mathrm{u}_{\mathrm{t}-2}+\ldots .
$$

We note that $R(1)=R_{0}+R_{1}+R_{2}+\ldots .=C(1) C_{0}^{-1}$. Form the matrix:

$$
R(1) \Sigma R(1)^{\prime}
$$

This matrix can be computed from the estimates of $\Sigma$ and $R(1)$ obtained from the reduced form (28). Using (25) to substitute for $\Sigma$ and the definition of $R(1)$ we see that:

$$
R(1) \Sigma R(1)^{\prime}=c(1) C(1)^{\prime} .
$$

Let $H$ denote the lower triangular Choleski decomposition of $R(1) \operatorname{LR}(1)$ ': 


$$
H H^{\prime}=R(1) \Sigma R(1)^{\prime}
$$

Now, our long run restrictions imply that $\mathrm{C}(1)$ is also lower triangular. Since $H$ is the unique lower triangular decomposition of $R(1) \sum R(1)^{\prime}$, we have:

$$
C(1)=H
$$

From the definition $R(1)=C(1) C_{0}^{-1},(23)$ implies:

$$
C_{0}=R(1)^{-1} H \text {. }
$$

Thus, the fact that the long run restrictions given by our model imply that $C(1)$ is lower triangular can be used to identify $C_{0}$. In practice, these restrictions are easy to impose: simply estimate the reduced form model and calculate $R(1)$, compute the unique lower triangular Choleski matrix $H$ where $H H^{\prime}=R(1) \sum R(1)^{\prime}$, and set $C_{0}=R(1)^{-1} H$. Given an estimate of $C_{0}$, we can recover the structural system dynamics defined by $C_{1}, C_{2}$, . - as well as the time series of structural shocks $\epsilon_{t}=\left[z_{t}, \delta_{t}, v_{t}\right]^{\prime}$ to supply, demand, and money. 


\section{Empirical Results}

In this section we present the empirical results that are at the heart of this paper. Using the structural VAR to recover the results and using our stochastic version of the Obstfeld (1985) open macro model to interpret the results, we seek to answer two questions: what are the sources of real exchange rate fluctuations since the collapse of Bretton Woods and, in particular, how important are nominal shocks? To answer these questions, we look at three complementary ways to summarize the results of a structural VAR: we calculate variance decompositions of the real exchange rate, we compute "real time" historical decompositions of the level of the real exchange rate, and we plot impulse responses of output, the real exchange rate, and inflation to the structural supply, demand, and nominal shocks to assess whether or not the shocks that our procedure identifies as supply, demand, and nominal "look like" supply demand and nominal shocks are supposed to look. That is, by investigating the impulse responses, we are checking whether or not our application of the Blanchard-Quah approach identifies structural shocks that "pass the duck test". ${ }^{6}$

We begin by reporting the results of two variance decomposition exercises for the $\log$ real exchange rate. In the first, reported in Table 3, the conditional variance of the level of the log real exchange rate $q_{t+k}$ at various horizons $k$ is split into the variance due to unforecastable structural monetary shocks $v_{t+j}$, unforecastable structural demand shocks, $\delta_{t+j}$, and unforecastable structural supply shocks $z_{t+j}, j=1, \ldots, k$. As can be seen from the results reported in Table 3 , nominal shocks account for a substantial 
fraction of the conditional variance of the level of the real exchange rate at short horizons in Germany and Japan. For example in Germany, more than 50 percent of the variance in forecasting the level of the real exchange rate at a horizon of 4 quarters is due to monetary shocks. More precisely, more than 50 percent of the 4 quarter variance in forecasting the $\log$ level of the real exchange rate is attributed to the shock in the system that has no long run effect on relative national output levels or the level of the real exchange rate. In Japan, more than one third, nearly 35 percent, of the variance in forecasting the level of the dollaryen real exchange rate at a horizon of 4 quarters is due to monetary shocks. According to our structural VAR, nominal shocks do not explain much of the variance in forecasting the level of the real exchange rate in Britain and Canada. For example in Britain, only 1.3 percent of the variance in forecasting the level of the real exchange rate at a horizon of 4 quarters is attributed to monetary shocks; in Canada, less than 1 percent of the 4 quarter forecast variance is due to nominal shocks. We shall discuss how to interpret these rather striking differences between the importance attributed to nominal shocks in Germany and Japan and the meager role attributed to nominal shocks in Britain and Canada after investigating other results yielded by our structural VARs.

For all four countries, of the remaining variance in forecasting the $\log$ level of the real exchange rate that is not attributed to nominal shocks, virtually all is attributed to demand shocks, and virtually none is attributed to supply shocks. For example in Germany, of the 49.6 percent of the variance in forecasting the level of the real exchange rate at a horizon of 4 quarters that is not due to monetary shocks, 42.7 
percent is attributed to demand shocks and only 6.9 percent is attributed to supply shocks. It will be recalled that we identify the demand shock as that shock in the system that has no long run effect on relative national output levels but that can have an effect on the real exchange rate in the long run.

In forecasting the level of an $I(1)$ variable such as $q_{t}$, the variance of the forecast error goes to infinity with the forecast horizon so that the share of this variance attributed to monetary shocks - which by assumption can have no long run effects on the level of $q_{t}$ - must go to zero with the forecast horizon.

Table 4 decomposes

the conditional variance of the change in the log real exchange rate $\Delta q_{t+k}$ at various horizons $k$ into fraction of the variance due to unforecastable structural monetary shocks $v_{t+j}$, demand shocks, $\delta_{t+j}$, and unforecastable supply shocks $z_{t+j}, j=1, \ldots, k$. As the forecast horizon increases, these conditional variance shares converge to the shares of the unconditional variance of the change in each real exchange rate due to supply, demand, and nominal shocks. As is evident from Table 4, this convergence is quite rapid - within 12 to 16 quarters. We see that 41.1 percent of the unconditional variance of the change in the dollar-DM real exchange rate is attributed to monetary shocks, 48.5 percent is attributed to demand shocks, and 10.4 percent is attributed to supply shocks. According to our decomposition, 35.2 percent of the unconditional variance of the change in the dollar-yen real exchange rate is attributed to monetary shocks, 61.2 percent is attributed to demand shocks, and 3.6 percent is attributed to supply shocks. 
As was the case for the decompositions of the level of the dollar. sterling and Canadian dollar real exchange rates reported in Table 3 , monetary shocks do not explain much of the unconditional variance of the change in either of the real exchange rates. For example, only 2.8 percent of the unconditional variance of the change in the dollar-sterling real exchange rate is attributed to monetary shocks, with the bulk of this variance, 91.1 percent, being attributed to demand shocks. Only 2.5 percent of the unconditional variance of the change in the US-Canadian dollar real exchange rate is attributed to monetary shocks.

We next present in Charts 9 - 12 historical "real time" decompositions of the level of each real exchange rate. The purpose of this exercise is to assess whether or not the supply, demand, and nominal shocks that our Identification scheme recovers can plausibly be held responsible for the time path followed by dollar real exchange rates since the collapse of Bretton Woods. In particular, we are interested in assessing the extent to which our historical decompositions match up with the Mundell-Fleming conventional wisdom about the dollar and policy mix (Sachs (1985); Feldstein (1992)) during the 1970s and 1980s. For example, it is one thing for our econometric strategy to identify monetary shocks that account for 41 percent of the variance in the change in the dollar-DM real exchange rate. However, these variance decompositions only make sense - at least to us - if episodes of "tight money" or "expansionary demand" correspond to periods of real dollar appreciation, and perlod of "loose money" or "contractionary demand" correspond to periods of real dollar depreciation. 
Chart 9 presents the results for the dollar-DM real exchange rate. This chart, and the next three, are constructed in the following way. In each panel, the solid line - newslogq - depicts the difference between the actual log level of the real exchange rate and the level that would have been forecasted based upon the history of the system up through 1974:3. Thus, newslogq in 1982:3 reflects the cumulative impact of the three structural shocks between 1974:4 and 1982:3. Each panel of Chart 9 compares the actual path of the real exchange rate with the path that would have prevailed if only one source of structural shocks had hit the system. The top panel of Chart 9 compares the actual path of the dollarDM real exchange rate with the path that would have been followed historically if only nominal shocks had hit the system, the center panel of the chart compares the actual path of the dollar-DM real exchange rate with the path that would have been followed historically if only demand shocks had hit the system, and the lower panel of Chart 9 compares the actual path of the dollar-DM real exchange rate with the path that would have been followed historically if only supply shocks had hit the system.

We find these result most interesting. As can be seen in the top panel of the chart, virtually all of the dollar's real depreciation against the DM in the late 1970s is attributed to nominal shocks, while most of the dollar's real appreciation against the DM in the first half of the 1980 s is attributed to demand shocks. Note, however, that a not insubstantial real dollar appreciation against the DM during the early 1980 s, one that would unwind the real depreciation of the late 1970s, is attributed to nominal shocks. of the dollar's post-Plaza real depreciation against the DM, roughly half is attributed to nominal shocks, 
and half is attributed to demand shocks. Supply shocks are not attributed a significant role in explaining the dollar-DM real exchange rate since the collapse of Bretton Woods.

Chart 10 presents the results for the dollar-yen real exchange rate. As is the case for the historical decomposition of the dollar-DM real exchange rate, the dollar's real depreciation against the yen in the late 1970 s is attributed to nominal shocks, while most of the dollar's real appreciation against the DM in the first half of the 1980 s is attributed to demand shocks. Note however that between 1979 and 1982, a real dollar appreciation against the yen that would be sufficient to unwind the real depreciation of the late 1970s, is attributed to nominal shocks. Supply shocks in favor of Japan are also attributed about 10 percentage points of the dollar's appreciation during the early 1980s. Of the dollar's postPlaza real depreciation against the yen, virtually all is attributed to demand shocks.

Charts 11 and 12 present the results for the dollar-sterling and dollar-Canadian dollar real exchange rates. (PLACE CHARTS 10 AND 11 HERE) Perhaps not surprisingly, in light of the variance decomposition results presented in Tables 3 and 4, monetary shocks are attributed only a trivial role in accounting for the history of the dollar - sterling and dollarCanadian dollar real exchange rates. For these currencies, the time path of the real exchange rate is essentially the time path attributed to demand shocks. To summarize, dollar-DM and dollar-yen real exchange rates are driven primarily by both money and demand shocks that produce a quite plausible history real exchanges, while dollar-sterling and Canadian dollar real exchange rates are driven almost exclusively by a shock that 
is identified to be a demand shock. For no real exchange rate, with the possible exception of the dollar-yen rate, are supply shocks identified to explain any substantial movement in real exchange rates.

We now investigate the impulse dynamics of the four estimated open macro models in response to the three structural shocks. Our objective to assess the extent to which shocks that our identification strategy identifies as due to demand, supply, and money generate dynamic and long run responses that are consistent with the Mundell-Fleming-Dornbusch model presented in section four. For example, according to that model, a demand shock in favor of US output should result in a real appreciation of the dollar, a rise in US prices, and a rise in US output if prices are sticky. To the extent that the demand shock is permanent, the model predicts that the real appreciation of the dollar will be permanent as well. A nominal shock which increases the US money supply or reduces US money demand relative to the foreign country should result in a nominal depreciation of the dollar, a rise in US prices, and a rise in US output and a real depreciation of the dollar if prices are sticky. To the extent that the shock to money supply or money demand is permanent, the model predicts that the nominal depreciation of the dollar will be permanent as well. Finally, a supply shock that boosts US output relative foreign output is predicted to result in a real depreciation of the dollar, a fall in US prices, and a rise in US output. To the extent that the demand shock is permanent, the model predicts that the real depreciation of the dollar will be permanent as well. 
Table 5 presents the impulse response results for the US-Germany structural VAR. In response to a one standard deviation nominal shock, the structural dynamics fit remarkably closely the predictions of the Mundell-Fleming-Dornbusch model. There is an initial 3.8 percent real depreciation of the dollar, a nearly 0.5 percent rise in Us output relative to German output, and a 0.3 percent rise in US inflation relative to German inflation. Chart 13A depicts this dynamic response, and reveals that the output and real exchange rate effects of a nominal shock die out after 16 to 20 quarters. Chart $13 \mathrm{~b}$ compares the impulse response of the nominal dollar-DM exchange rate with the real dollar-DM exchange rate. We see that the nominal dollar-DM exchange rate overshoots substantially: in the long run the dollar depreciates by 1.7 percent against the DM, while initially the nominal dollar-DM exchange rate depreciates by more than 4 percent. We also note that the nominal dollar-DM exchange rate does not appreciate monotonically but that, instead, the exchange rate depreciates for several quarters following the nominal shock. Indeed the maximum depreciation is not achieved until 4 quarters after the initial nominal shock. This phenomenon has been recently uncovered using a completely different empirical strategy by Eichenbaum and Evans (1993). We shall compare our findings and approach with the Eichenbaum and Evans paper in section six. Table 5 also presents the impulse response dynamics to a demand shock. Again, the structural dynamics fit remarkably closely the predictions of the Mundell-Fleming-Dornbusch model. There is an initial 4 percent real appreciation of the dollar, a 0.36 percent rise in US output relative to German output, and a 0.44 percent rise in US inflation relative to German 
inflation. In the long run, the demand shock causes the dollar to appreciate by more than percent against the DM in real terms. The table also presents the impulse responses to a one standard deviation supply shock. Although US prices fall initially in response to the supply shock, the dollar appreciates in real terms, in contradiction to the open macro model presented above. In the long run, the real dollar-DM exchange rate is essentially unchanged, even though the supply shock is forecasted to have a permanent effect on US relative to German output.

Table 6 present the results for the US-Japan structural VAR.

As can be seen from the table, the impulse responses to a nominal shock match the predictions of the theoretical model presented earlier. There is an initial 3.4 percent real depreciation of the dollar, a 0.56 percent rise in US output relative to Japanese output, and a 0.33 percent rise in US inflation relative to Japanese inflation.

Chart 14A depicts this dynamic response, and reveals that the output and real exchange rate effects of a nominal shock die out after 12 to 16 quarters. i As shown in Chart 14B, the dollaryen nominal exchange rate overshoots: in the long run nominal dollar-yen exchnage rate depreciates by 1.2 percent, while initially the dollar depreciates by more than 3.5 percent against the yen. As is the case for the dollar-DM, the nominal dollar-yen exchange rate does not appreciate monotonically but, instead, depreciates for two quarters following the nominal shock. Table 6 also presents the impulse responses to a one standard deviation demand shock. There is an initial 4.4 percent real appreciation of the dollar-yen exchange rate, a 0.36 percent rise in US output relative to German output, and a nearly 0.43 percent rise in US 
inflation relative to German inflation. In the long run, the demand shock causes the dollar to appreciate by 5.5 percent against the yen in real terms. Finally, and in contrast to the US-German results, the real dollar-yen exchange rate depreciates in response to a supply shock that boosts US output relative Japanese output, just as predicted by the theoretical presented above.

Tables 6 and 7 present the impulse response results for Britain and Canada . : For the most part, the results for these two countries are similar to those we have just discussed in detail for Germany and Japan. Nominal shocks lead to short run real depreciation, a rise in US output, and a jump in US inflation. Demand shocks lead to short and long run real appreciation, a temporary rise in US output, and a temporary jump in US inflation. In Canada, supply shocks boost relative US output, lower temporarily US inflation, and lead to a short and long run real depreciation of the dollar. In Britain, the results are qualitatively close to those reported for Germany: a supply shock that boosts US output relative to British is forecasted to result in a real appreciation of the dollar-sterling exchange rate, in contradiction to the theoretical model. 


\section{Concluding Remarks}

For two of the four countries we have investigated, Japan and Germany, our structural VAR estimates imply that nominal shocks explain a substantial amount of the variance in dollar-DM and dollar-yen real exchange rates. In particular, we find that more than 41 percent of the unconditional variance of the change in the dollar-DM real exchange rate, and more than 35 percent of the variance of the change in the dollar-yen real exchange rate are attributed to nominal shocks. Expressed in terms of conditional forecasts, we find that 45 percent of the 4 -quarter ahead forecast error variance of the log level of the dollar-DM real exchange rate is attributed to nominal shocks, and that 34 percent of the 4 quarter forecast variance of the log dollar-yen real exchange rate is attributed to nominal shocks.

For the other two countries we study, Canada and Britain, our structural VAR estimates imply that nominal shocks explain very little of the variance in real exchange rates. At one level, the reason for these contrasting results is easy to understand. Given the information set implied by our structural model, very little of the change in either the dollar-sterling or the dollar-Canadian dollar real exchange rate is forecastable, a fact documented with our non-structural Beveridge-Nelson decompositions. It follows that our, or any, structural model that uses this information set will be unable to attribute much to nominal shocks which can only have a transitory effect on the real exchange rate. Perhaps a different, or larger, Information set would imply much greater forecastablility in the dollar-sterling and the dollar-Canadian dollar real exchange rates. However, it should be noted that achieving 
identification with a larger information set might very prove to be a daunting task. We have not attempted this, and leave this as a topic for future research.

Our findings for the dollar-DM and dollar-yen real exchange rates are quite consistent with those reported recently in an insightful paper by Eichenbaum and Evans (1992). Eichenbaum and Evans attempt to isolate the innovations in monetary policy using VARs that include either federal funds rate or the ratio of non-borrowed to total reserves. Their VARs also include either a nominal or real exchange rate as well as US and foreign output and prices. These authors find that from between 13 percent to 42 percent of the 12 - quarter ahead forecast error variance of the log level of the dollar-DM real exchange rate is attributed to US monetary policy innovations depending upon how they specify the system, and they report that from between 13 to 23 percent of the 12 - quarter ahead forecast error variance of the log dollar-yen real exchange rate is attributed to US monetary policy innovations. ${ }^{7}$ As can be seen from our Table 3, our structural VAR approach attributes 28 percent of the 12 quarter ahead forecast error variance of the log level of the dollar-DM real exchange rate to nominal shocks, and it attributes 15 percent of the 12 - quarter ahead forecast error variance of the log dollar-yen real exchange rate to nominal shocks. Thus, our estimates of the contribution of nominal shocks to explaining the short run variance in forecasting the log levels of the dollar-DM and dollar-yen real exchange rates are near the respective midpoints of the estimates presented in Eichenbaum and Evans (1992).8 
A recent paper by Lastrapes (1992) also uses the Blanchard-Quah identification strategy to estimate the importance of nominal shocks in explaining the behavior of real exchange rates. Unlike our paper, Lastrapes does not claim to, and his approach cannot, identify an open economy macro model with his structural VAR. He investigates bivariate VARs containing changes in the log real exchange rate and changes in the log nominal exchange rate. Thus, his system can only identify two shocks, a "real" and a "nominal" shock. In particular, his system cannot distinguish between supply and demand shocks. Lastrapes (1992) acknowledges that if the world is subject to more than a single real shock, his identification strategy is potentially compromised. Perhaps for this reason, our estimates of the importance of nominal shocks for the dollar-DM and dollar-yen real exchange rates substantially exceed those reported in Lastrapes (1992). For example, whereas we find that 45 percent ( 34 percent) of the 4 - quarter ahead forecast error variance of the log level of the dollar-DM (dollar-yen) real exchange rate is attributed to nominal shocks, Lastrapes only attributes 27 percent ( 6 percent).

One contribution of this paper has been to demonstrate that the short run dymamic responses of relative national outputs, prices, and the real exchange rate to nominal, demand, and, at least for Japan and Canada, supply shocks are consistent with the predictions of a stochastic, rational expectations version of the textbook Mundell-Fleming model. These findings, along with the variance and historical decompositions reported above, and the complementary findings reported in Eichenbaum and Evans (1992), suggest to us that sluggish price adjustment must be 
incorporated into any effort to explain short run fluctuations in real exchange rates (Mussa (1986)). This being said we also note that, according to our estimates, real shocks to supply and demand account for more than 50 percent of the variance in forecasting real exchange rates except at short horizons for the dollar-DM real exchange rate. Campbell and Clarida (1987) and Stockman (1987) have emphasized "real" explanations for real exchange rate volatility. Our findings do not suggest that these efforts are misplaced. Obviously, real shocks must be present if we are to believe the many papers that find evidence of a unit root in the real exchange rate since the collapse of Bretton Woods. 
REFERENCES

Adler, M. and B. Lehman, "Deviations from Purchasing Power Parity in the Long Run," Journal of Finance, (39) 1983, 1471 - 1487.

Baster, M., "Real Exchange Rates, Real Interest Rates, and Government Policy: Theory and Evidence," mimeo, University of Rochester, February 1988.

Beveridge, S. and C. Nelson, "A New Approach to the Decomposition of Economic Time Series Into Permanent and Transitory Components," Journal of Monetary Economics, (7) $1981,151-174$.

Bayoumi, T. and B. Eichengreen, "Macroeconomic Adjustment under Bretton Woods and the Post Bretton Woods Float," NBER Working paper No. 4169, September 1992.

Blanchard, O., and D. Quah, "The Dynamic Effects of Aggregate Demand and Supply Disturbances, "American Economic Review, (79) 1989, 655 673.

Branson, W., "Exchange Rate Dynamics and Monetary Policy," in Lindbeck, ed., Inflation and Employment in open Economies, Amsterdam: North Holland, 1979, $189-224$. 
Campbell, J. and R. Clarida, "The Dollar and Real Interest Rates: An Empirical Investigation," Carnegie-Rochester Conference Series on Public Policy, (27) $1987,103-140$.

Cochrane, J., "Univariate vs Multivariate Forecasts of GNP Growth and Stock Returns," NBER Working Paper No. 3427, 1990.

Cumby, R. and J. Huizinga, "The Predictability of Real Exchange Rate Changes in the Short Run and the Long Run," NBER Working Paper No. 3468, October 1990.

Cumby, J. and M. Obstfeld, "International Interest Rate and Price Level Linkages Under Flexible Exchange Rates," in Bilson and Marston eds., Exchange Rate Theory and Practice, Chicago: University of Chicago Press, 1984.

Dornbusch, R., "Expectations and Exchange Rate Dynamics," Journal of Political Economy, (84) 1976, 1161 - 1176.

Eichenbaum, M. and C. Evans, "Some Empirical Evidence on the Effects of Monetary Policy Shocks on Exchange Rates," mimeo, FRB Chicago, December 1992.

Edison, H. and D. Pauls, "A Re-Assessment of the Relationship Between Real Exchange Rates and Real Interest Rates," Journal of Monetary Economics, (29) 1993. 
Evans, G., "A Measure of the US Output Gap," Economics Letters, 1989 $(29), 285-289$.

Evans, C. and L. Reichlin, "Information, Forecasts, and Measurement of the Business Cycle," mimeo, Columbia University, May 1993.

Evans, M. and J. Lothian, "The Response of Exchange Rates to Permanent and Transitory Shocks under Floating Exchange Rates," mimeo, Stern School of Business, April 1992.

Feldstein, M., "The Dollar and the Trade Deficit," NBER Working Paper No. 4325, April 1993.

Frankel, J., "On the Mark: A Theory of Floating Exchange Rates Based on Real Interest Differentials," American Economic Review, (69) $1979,610-622$.

......, "The Dazling Dollar," Brookings Papers on Economic Activity, I, 1985.

Frenkel, J., "Flexible Exchange Rates, Prices, and the Role of News: Lessons from the 1970s," Journal of Political Economy , (83) 1981 , $655-705$.

Flood, R., "Explanations of Exchange Rate Volatility and other Empirical Regularities in Some Popular Models of the Foreign 
Exchange Market," Carnegie-Rochester Conference Series on Public Policy, (15) 1981 .

Gali, J., "How Well Does the IS-LM Model Fit Postwar US Data?" Quarterly Journal of Economics, 1992, $709-738$.

Grilli, V. and G. Kaminsky, "Nominal Exchange Rate regimes and the Real Exchange Rate," Journal of Monetary Economics, (27) 1991, 191 212.

Hansen, L. and R. Hodrick, "Risk Averse Speculation in the Forward Foreign Exchange Market: An Econometric Analysis of Linear Models," in Frenkel ed., Exchange Rates and International Macroeconomics, Chicago: University of Chicago Press, 1983.

Hodrick, R., The Empirical Evidence on the Efficiency of Forward and Futures Foreign Exchange Markets, London: Harwood Publishers, 1987.

Huizinga, J., "An Empirical Investigation of the Long Run Behavior of Real Exchange Rates," Carnegie-Rochester Conference Series on Public Policy, (27) $1987,149-215$.

King, R., C. Plosser, J. Stock, and M. Watson, "Stochastic Trends and Economic Fluctuations," American Economic Review, (81) 819 839. 
Lastrapes, W., "Sources of Fluctuations in Real and Nominal Exchange Rates," Review of Economics and Statistics, 1992, $530-539$.

Lippi, M. and L. Reichlin, "The Dynamic Effects of Aggregate Demand and Supply Disturbances: Comment," American Econoimc Review, (83) 1993.

Loopesko, B. and J. Shafer, "Floating Exchange Rates After Ten Years," Brookings Papers on Economic Activity 1, 1983, 1 - 86.

Melzter, A., "Real Exchange Rates: some Evidence from the Postwar Years," Federal Reserve Bank of St. Louis, May 1993, 103 - 117.

Obstfeld, M., "Floating Exchange Rates: Experience and Prospects," Brookings Papers on Economic Activity 2, 1985, $369-450$.

Meese, R. and K. Rogoff, "Was it Real? The Exchange Rate Interest Differential Relation Over the Modern Floating Rate Period," Journal of Finance, (43), $933-948$.

Mussa, M., "A Model of Exchange Rate Dynamics," Journal of Political Economy, (90), 1982, $74-104$.

Mussa, M., "Nominal Exchange Rate Regimes and the Behavior of Real Exchange Rates: Evidence and Implications," Carnegie-Rechester Conference Series on Public Policy, (26) 1986. 
Roll, R., "Violations of Purchasing Power Parity and Their Implications for Efficient International Commodity Markets," in Sarnat and Szego, eds., International Finance and Trade, Cambridge: Ballinger Press, 1979.

Sachs, J., "The Dollar and the Policy Mix," Brookings Papers on Economic Activity 1, 1985, $117-185$.

Shapiro, M. and M. Watson, "Sources of Business Cycle Fluctuations," NBER Macroeconomics Annual 1988.

Stockman, A., "The Equilibrium Approach to Exchange Rates," Federal Reserve Bank of Richmond Economic Review, 1987.

........, "Real Exchange Rate Variability Under Pegged and Floating Nominal Exchange Rate Systems: An Equilibrium Theory," Carnegie-Rochester Conference Series on Public Policy, (29) 1988, $259-294$. 
</ref_section> 
NOTES

* Clarida, Department of Economics and School of International and Public Affairs, Columbia University, and The National Bureau of Economic Research. Gali, Graduate School of Business, Columbia University, and the Centre for Economic Policy Research. We would like to thank Lucrezia Reichlin, Charles Evans, Mike Gavin, Steve Husted, Allan Meltzer, Charles Plosser, Alan Stockman, and participants at the November 1992 Carnegie Rochester Conference on Public Policy for their comments and suggestions. Parts of this paper were written while Clarida was visiting the International Monetary Fund, and while Gali was visiting the Universitat Pompeu Fabra. The authors would like to thank these institutions for their hospitality. The authors would also like to thank seminar participants at Columbia University, the University of Pittsburgh, the Paris Macroeconomics Workshop, and CEMFI - Madrid for their comments on earlier drafts of this paper. Any errors or confusions that remain are those of the authors.

1. The exception is Japan, for which we investigate the slightly shorter sample period 1975:3 - 1992:4. We do this for comparability with the results presented above for the Japan $\left[\Delta q_{t}, r_{t}\right]$ system for which our Euromarket data only become available in 1975:3. Following Hansen and Hodrick ((1983) pp. 120-121), we also investigated samples for Germany, Canada, and Britain that "excluded the transitional early years of the floating exchange rate era". As Hansen and Hodrick point out, it was not until November 1975 that the G6 countries "produced an agreement which led directly to the amendments to the Articles of Agreement of the IMF which 
formally ratified the flexible exchange rate system." While none of the results for Germany, Britain, or Canada reported in this paper are sensitive to the choice of a starting date of $73: 3$ vs $75: 3$, some of the results for Japan are. Data sources are as follows: CPI data are from the IFS tape; the spot exchange rates and the Euromarket interest rates are point sampled from a data base maintained by the Federal Reserve Bank of New York; the real GDP data is from the OECD Main Economic Indicators.

2. For expository convenience, and to parallel the bulk of the literature on "sticky price" open macro models cited above, we follow Obstfeld (1985) and do not explicitly incorporate the accumulation of foreign assets (debts) via current account surpluses (deficits) that may result from the shocks we study. We also ignore a time varying risk premium. Later we shall discuss the empirical implications of a risk premium for the empirical strategy we pursue.

3. The two country obstfeld (1985) model we study has the property that the home relative to the foreign market clearing price level is invariant to a permanent relative demand shock. This is not a general property of an open-macro equilibrium so we do not use it for identification.

4. The stochastic version of Obstfeld's (1985) model that we use to motivate our identification strategy ignores, as does the bulk of the literature, a time varying risk premium. If the equilibrium risk premium is a stationary stochastic process that is a function of the three structural shocks - to supply, demand, and money - on which we focus, 
identification goes through as in the case, discussed in the text, in which the risk premium is assumed to be constant. However, the closedform solution to the model is a great deal more cumbersome.

5. See Edison and Pauls (1993) for empirical evidence using quarterly data since 1974:3 that $q_{t}$ is $I(1)$ and that $\pi^{\text {us }}{ }_{t}-\pi_{t}$ is $I(0)$ in the four countries we study. To test the hypothesis that $y^{u s} s_{t}-y_{t}$ is $I(1)$ in each country, we ran augmented Dickey-Fuller t-tests and could not reject the null of a unit root in any of these four countries. Our theoretical model also implies that there exists no cointegrating relationships among $y_{t}, q_{t}$, and $p_{t}$. Tests for cointegration among $\left[y_{t}, q_{t}, p_{t}\right]$ were performed using Johansen's (1991) maximum likelihood procedure. For Germany and Japan, we could not reject the null of no cointegration among these variables at even the 20 percent significance level; for Britain, we could not reject the null of no cointegration at the 10 percent level. For Canada, there does appear to be evidence of a single cointegrating vector among these three variables.

6. If it walks like a duck and quacks like a duck, it must be..

7. Eichenbaum and Evans use monthly data; thus their results are reported for 36 month horizon.

8. Eichenbaum and Evans do not include Canada in their study. They find that innovations to US monetary policy account for from between 11 percent to 26 percent of the variance in forecasting the $\log$ level of the dollarsterling exchange rate at a horizon of 36 months. From Table 3 , we see 
that we estimate that less than 1 percent of this variance is due to nominal shocks. 
TABLE 1

Transitory-Actual Variance Ratios

$\operatorname{var}\left(\Delta q^{5 r_{t}}\right) / \operatorname{var}\left(\Delta q_{t}\right)$

\begin{tabular}{lc} 
Country & Bivariate System \\
\hline Germany & 0.05 \\
Japan & 0.03 \\
Britain & 0.10 \\
Canada & 0.23
\end{tabular}

$\left[\Delta q_{t}, r_{t}\right]$ VARs

\begin{tabular}{|c|c|c|c|c|}
\hline & \multicolumn{2}{|c|}{ Germany } & \multicolumn{2}{|c|}{ Japan } \\
\hline & $R^{2}$ & Exclude & $R^{2}$ & Exclude \\
\hline & & $\Delta q$ & & $\Delta q$ \\
\hline .......... & . . . . . . & 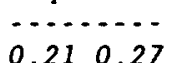 & 0.00 & 0.490 .41 \\
\hline$r$ & 0.26 & $0.03 \quad 0.01$ & 0.28 & 0.170 .01 \\
\hline
\end{tabular}

- . . . . .

Equation

-........

- . . . . . .

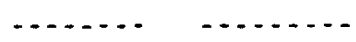

$$
\text { Canada }
$$

$\Delta q$

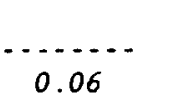

Exclude

$\Delta q \quad r$

$\begin{array}{ccc}R^{2} & \text { Britain } \\ & \Delta q & r \\ 0.13 & 0.01 & 0.37\end{array}$

$r$

0.15

0.440 .63

0.270 .07

- . . . .

-......

0.040 .05

0.10

0.270 .07

Tests of Cross-Equation Restrictions

$\begin{array}{lcc} & x^{2}(8) & \text { Significance } \\ \text { Germany } & 19.53 & 0.02 \\ \text { Japan } & 10.43 & 0.23 \\ \text { Britain } & 21.43 & 0.01 \\ \text { Canada } & 18.09 & 0.02\end{array}$

The sample is 1974:3 - 1992:1 except Japan which is 1976:3 -

$1992: 1 . R^{2}$ is adjusted for degrees of freedom. "Exclude" reports the significance level for an F-test that a variable can be excluded from an equation of the VAR. The crossequation restrictions are those defined by equation (7) in the text. 
TABLE 2

Transitory-Actual Variance Ratios

\begin{tabular}{lcc} 
& \multicolumn{3}{c}{$\operatorname{var}\left(\Delta q_{\ell}^{\mathrm{BN}}\right) / v a r\left(\Delta q_{\ell}\right)$} \\
Country & Trivariate System & Univariate System \\
Ciermany & 0.705 & 0.235 \\
Japan & 0.591 & 0.233 \\
Britain & 0.385 & 0.146 \\
Canada & 0.210 & 0.143
\end{tabular}

$\left[\Delta \mathbf{y}_{t}, \Delta \mathbf{q}_{\mathrm{t}}, \boldsymbol{\pi}_{\mathrm{t}}\right]$ VARS

\begin{tabular}{|c|c|c|c|c|c|c|}
\hline \multirow[b]{3}{*}{ Equation } & \multicolumn{4}{|c|}{ Germany } & \multicolumn{2}{|c|}{ Japan } \\
\hline & \multirow[t]{2}{*}{$R^{2}$} & \multicolumn{3}{|c|}{ Exclude } & \multirow[t]{2}{*}{$R^{2}$} & Exclude \\
\hline & & $\Delta y$ & $\Delta q$ & $\pi$ & & $\Delta y \quad \Delta q$ \\
\hline - - & $\cdots$ & $\cdots$ & $a^{0}$ & $\bar{a}^{2}$ & 19 & 073013002 \\
\hline$\Delta y$ & 0.02 & 0.10 & 0.91 & 0.40 & 0.19 & 0.730 .130 .02 \\
\hline$\Delta q$ & 0.14 & 0.63 & 0.21 & 0.02 & 0.04 & $\begin{array}{llll}0.75 & 0.74 & 0.09\end{array}$ \\
\hline$\pi$ & 0.31 & 0.82 & 0.19 & 0.01 & 0.48 & 0.910 .110 .01 \\
\hline$\cdots$ & - & $-\cdots$ & & & -6 & $\cdots$ \\
\hline
\end{tabular}

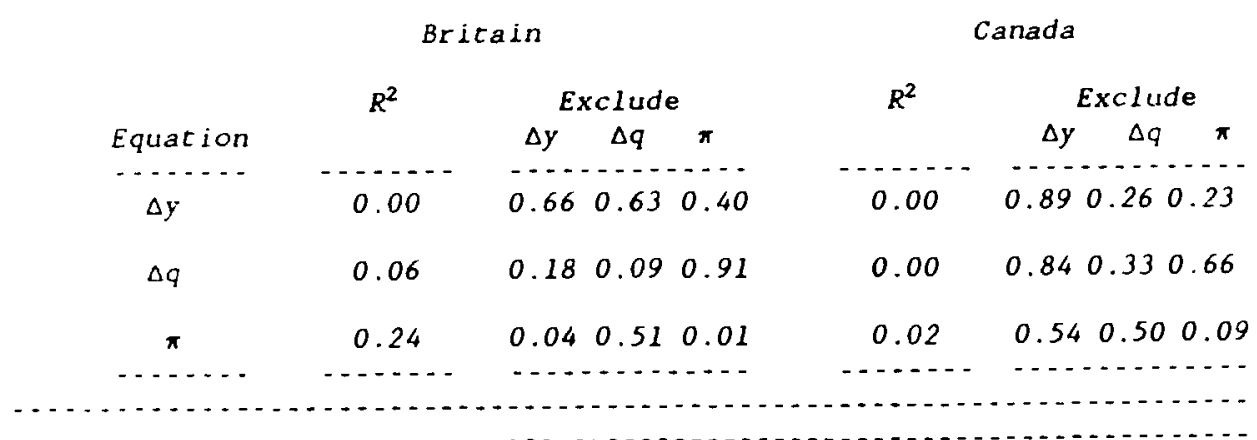

Trivariate VAR includes a constant and four lagged values of $\Delta q_{t}$, the change in the log real exchange rate, $\Delta y_{t}$, the change in the log ratio of US to foreign real GDP, and $\pi_{t}$, the difference between US and foreign inflation. The sample is 1974:3 - 1992:4 except for Japan which is $1976: 3-1992: 4$ 
TABLE 3

\section{Variance Decomposition $-q_{t}$}

\begin{tabular}{|c|c|c|}
\hline & Germany & Japan \\
\hline & $\ldots . .$. & $\cdots$ \\
\hline & $\begin{array}{c}\text { fraction of variance } \\
\text { due to }\end{array}$ & $\begin{array}{c}\text { fraction of variance } \\
\text { due to }\end{array}$ \\
\hline Horizon & Supply Demand Money & Supply Demand Money \\
\hline$\cdots$ & $\cdots+\cdots, \cdots$ & - \\
\hline 1 & $\begin{array}{lll}0.007 & 0.518 & 0.474\end{array}$ & $\begin{array}{lll}0.009 & 0.631 & 0.359\end{array}$ \\
\hline & $(0.076)(0.262)(0.267)$ & $(0.107)(0.233)(0.221)$ \\
\hline 2 & $\begin{array}{lll}0.034 & 0.435 & 0.531\end{array}$ & $\begin{array}{ccc}0.005 & 0.664 & 0.331\end{array}$ \\
\hline & $(0.099)(0.243)(0.251)$ & $(0.107)(0.224)(0.217)$ \\
\hline 3 & $\begin{array}{ccc}0.067 & 0.408 & 0.525 \\
(0.117)(0.232) & (0.242)\end{array}$ & $\begin{array}{ccc}0.003 & 0.650 & 0.347\end{array}$ \\
\hline 4 & $\begin{array}{ccc}0.1179 & 0.427 & 0.504\end{array}$ & $\begin{array}{ccc}0.002 & 0.650 & 0.347\end{array}$ \\
\hline & $(0.118)(0.229)(0.238)$ & $(0.107)(0.220)(0.214)$ \\
\hline 8 & $\begin{array}{llll}0.039 & 0.575 & 0.386\end{array}$ & $\begin{array}{lll}0.004 & 0.779 & 0.216\end{array}$ \\
\hline & $(0.113)(0.207)(0.202)$ & $(0.109)(0.199)(0.173)$ \\
\hline 12 & $\begin{array}{lll}0.026 & 0.692 & 0.282\end{array}$ & $0.010 \quad 0.836 \quad 0.153$ \\
\hline & $(0.117)(0.167)(0.145)$ & $(0.117)(0.179)(0.132)$ \\
\hline 16 & $\begin{array}{lll}0.019 & 0.766 & 0.214\end{array}$ & $0.016 \quad 0.863$ \\
\hline & $(0.121)(0.142)(0.104)$ & $(0.124)(0.166)(0.103)$ \\
\hline 20 & $\begin{array}{lll}0.016 & 0.811 & 0.172\end{array}$ & $0.020 \quad 0.880$ \\
\hline & $(0.125)(0.134)(0.082)$ & $(0.128)(0.159)(0.085)$ \\
\hline & Britain & Canada \\
\hline & $\ldots . .$. & $\ldots . .$. \\
\hline & fraction of variance & fraction of variance \\
\hline & due to & due to \\
\hline orizon & Supply Demand Money & Supply Demand Money \\
\hline$\ldots$ & 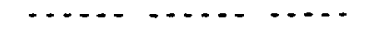 & 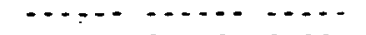 \\
\hline 1 & 0.973 & 0.007 \\
\hline & $(0.123)(0.214)(0.177)$ & $(0.112)(0.150)(0.111)$ \\
\hline 2 & 0.979 & 0.013 \\
\hline & $(0.112)(0.197)(0.152)$ & $(0.118)(0.150)(0.104)$ \\
\hline 3 & 0.9690 .018 & 0.011 \\
\hline & $(0.111)(0.187)(0.138)$ & $(0.121)(0.144)(0.085)$ \\
\hline 4 & $0.952 \quad 0.013$ & $0.977 \quad 0.004$ \\
\hline & $(0.110)(0.171)(0.121)$ & $(0.127)(0.145)(0.072)$ \\
\hline 8 & $0.954 \quad 0.007$ & 0.960 \\
\hline & $(0.121)(0.143)(0.079)$ & $(0.141)(0.157)(0.044)$ \\
\hline 12 & $0.954 \quad 0.004$ & 0.9510 .003 \\
\hline & $(0.129)(0.139)(0.055)$ & $(0.162)(0.172)(0.027)$ \\
\hline 16 & $0.954 \quad 0.003$ & 0.946 \\
\hline & $(0.138)(0.139)(0.039)$ & $(0.177)(0.183)(0.018)$ \\
\hline 20 & $\begin{array}{lll}0.044 & 0.954 & 0.002\end{array}$ & $0.054 \quad 0.943$ \\
\hline & $(0.144)(0.144)(0.031)$ & $(0.187)(0.191)(0$ \\
\hline
\end{tabular}

Value in parentheses is empirical standard error computed from Monte Carlo simulation. VAR specification as reported in notes to Table 2. 
TABLE 4

Variance Decomposition - $\Delta q_{t}$

\begin{tabular}{|c|c|c|}
\hline & Germany & Japan \\
\hline & $\ldots . .$. & $\ldots$. \\
\hline & $\begin{array}{c}\text { fraction of variance } \\
\text { due to }\end{array}$ & $\begin{array}{c}\text { fraction of variance } \\
\text { due to }\end{array}$ \\
\hline Horizon & Supply Demand Money & Supply Demand Money \\
\hline$\cdots$ & $\cdots+\cdots$ & $\cdots, \cdots$ \\
\hline 1 & $\begin{array}{lll}0.007 & 0.518 & 0.474\end{array}$ & $0.009 \quad 0.631$ \\
\hline & $(0.097)(0.285)(0.286)$ & $(0.134)(0.231)(0.203)$ \\
\hline 2 & $\begin{array}{llll}0.035 & 0.497 & 0.468\end{array}$ & $\begin{array}{llll}0.028 & 0.630 & 0.341\end{array}$ \\
\hline & $(0.102)(0.253)(0.256)$ & $(0.119)(0.216)(0.188)$ \\
\hline 3 & $\begin{array}{llll}0.046 & 0.487 & 0.467\end{array}$ & $0.031 \quad 0.630 \quad 0.338$ \\
\hline & $(0.098)(0.242)(0.248)$ & $(0.114)(0.202)(0.177)$ \\
\hline 4 & $0.046 \quad 0.503 \quad 0.450$ & $\begin{array}{lll}0.034 & 0.627 & 0.339\end{array}$ \\
\hline & $(0.094)(0.229)(0.234)$ & $(0.116)(0.198)(0.172)$ \\
\hline 8 & $\begin{array}{llll}0.096 & 0.500 & 0.404\end{array}$ & $\begin{array}{lll}0.035 & 0.617 & 0.347\end{array}$ \\
\hline & $(0.084)(0.187)(0.191)$ & $(0.113)(0.167)(0.145)$ \\
\hline 12 & $\begin{array}{llll}0.103 & 0.489 & 0.407\end{array}$ & $\begin{array}{llll}0.036 & 0.612 & 0.352\end{array}$ \\
\hline & $(0.082)(0.173)(0.179)$ & $(0.114)(0.167)(0.144)$ \\
\hline 16 & $\begin{array}{lll}0.104 & 0.485 & 0.411\end{array}$ & $0.036 \quad 0.612$ \\
\hline & $(0.080)(0.168)(0.174)$ & $(0.117)(0.167)(0.144)$ \\
\hline 20 & $\begin{array}{lll}0.104 & 0.485 & 0.411\end{array}$ & $\begin{array}{lll}0.036 & 0.612 & 0.352\end{array}$ \\
\hline & $(0.080)(0.166)(0.172)$ & $(0.119)(0.167)(0.144)$ \\
\hline & Britain & Canada \\
\hline & $-\ldots .$. & $\ldots .$. \\
\hline & fraction of variance & fraction of variance \\
\hline & due to & due to \\
\hline Horizon & Supply Demand Money & Supply Demand Money \\
\hline$\cdots \cdot$ & $\cdots+\cdots$ & 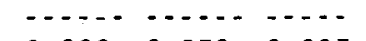 \\
\hline 1 & $\begin{array}{ccc}0.005 & 0.973 & 0.022 \\
(0.096) & (0.167) & (0.147)\end{array}$ & $\begin{array}{ccc}0.022 & 0.970 & 0.007 \\
(0.124) & (0.173)(0.125)\end{array}$ \\
\hline 2 & $\begin{array}{lll}0.020 & 0.959 & 0.021\end{array}$ & $\begin{array}{lll}0.032 & 0.959 & 0.007\end{array}$ \\
\hline & $(0.093)(0.159)(0.138)$ & $(0.121)(0.169)(0.125)$ \\
\hline 3 & $\begin{array}{lll}0.034 & 0.946 & 0.019\end{array}$ & $\begin{array}{lll}0.035 & 0.952 & 0.012\end{array}$ \\
\hline & $(0.096)(0.158)(0.136)$ & $(0.120)(0.166)(0.118)$ \\
\hline 4 & $\begin{array}{lll}0.055 & 0.919 & 0.025\end{array}$ & $\begin{array}{lll}0.045 & 0.943 & 0.012\end{array}$ \\
\hline & $(0.101)(0.146)(0.121)$ & $(0.124)(0.163)(0.107)$ \\
\hline 8 & $\begin{array}{llll}0.061 & 0.911 & 0.027\end{array}$ & $\begin{array}{lll}0.043 & 0.934 & 0.023\end{array}$ \\
\hline & $(0.098)(0.139)(0.112)$ & $(0.121)(0.163)(0.109)$ \\
\hline 12 & $\begin{array}{llll}0.061 & 0.911 & 0.028\end{array}$ & $\begin{array}{lll}0.043 & 0.932 & 0.025\end{array}$ \\
\hline & $(0.099)(0.139)(0.112)$ & $(0.124)(0.164)(0.109)$ \\
\hline 16 & $\begin{array}{lll}0.061 & 0.911 & 0.028\end{array}$ & $\begin{array}{lll}0.043 & 0.932 & 0.025\end{array}$ \\
\hline & $(0.098)(0.138)(0.112)$ & $(0.125)(0.165)(0.109)$ \\
\hline 20 & $\begin{array}{llll}0.061 & 0.911 & 0.028\end{array}$ & $\begin{array}{lll}0.043 & 0.932 & 0.025\end{array}$ \\
\hline & $(0.098)(0.138)(0.112)$ & $(0.126)(0.165)(0.10$ \\
\hline
\end{tabular}

Value in parentheses is empirical standard error computed from Monte Carlo simulation. VAR specification as reported in notes to Table 2. 
TABLE 5

US-GERMAN IMPULSE RESPONSES TO MONETARY SHOCK

$\begin{array}{rccc} & \mathrm{y}_{\mathrm{t}} & \mathrm{q}_{\mathrm{t}} & \boldsymbol{\pi}_{\mathrm{t}} \\ 1 & .462488 \mathrm{E}-02 & .377507 \mathrm{E}-01 & .315902 \mathrm{E}-02 \\ 2 & .349914 \mathrm{E}-02 & .453675 \mathrm{E}-01 & .193356 \mathrm{E}-02 \\ 3 & .247230 \mathrm{E}-02 & .388801 \mathrm{E}-01 & .106539 \mathrm{E}-02 \\ 4 & .304892 \mathrm{E}-02 & .429423 \mathrm{E}-01 & .118095 \mathrm{E}-02 \\ 5 & .478072 \mathrm{E}-02 & .430385 \mathrm{E}-01 & .234435 \mathrm{E}-02 \\ 6 & .339958 \mathrm{E}-02 & .376681 \mathrm{E}-01 & .160408 \mathrm{E}-02 \\ 7 & .261366 \mathrm{E}-02 & .338672 \mathrm{E}-01 & .722475 \mathrm{E}-03 \\ 8 & .279930 \mathrm{E}-02 & .313912 \mathrm{E}-01 & .882155 \mathrm{E}-03 \\ 12 & .152576 \mathrm{E}-02 & .145464 \mathrm{E}-01 & .380088 \mathrm{E}-03 \\ 16 & .507210 \mathrm{E}-03 & .409438 \mathrm{E}-02 & .697164 \mathrm{E}-04 \\ 20 & . .108420 \mathrm{E}-18 & .346945 \mathrm{E}-17 & -.445969 \mathrm{E}-04\end{array}$

US-GERMAN IMPULSE RESPONSES TO DEMAND SHOCK

$\begin{array}{rccc} & \mathrm{y}_{\mathrm{t}} & \mathrm{q}_{\mathrm{t}} & \pi_{\mathrm{t}} \\ 1 & .358595 \mathrm{E}-02 & -.395005 \mathrm{E}-01 & .441176 \mathrm{E}-02 \\ 2 & .110734 \mathrm{E}-02 & -.359415 \mathrm{E}-01 & .327817 \mathrm{E}-03 \\ 3 & .845930 \mathrm{E}-03 & -.320154 \mathrm{E}-01 & -.959306 \mathrm{E}-03 \\ 4 & .785902 \mathrm{E}-03 & -.436595 \mathrm{E}-01 & .448387 \mathrm{E}-03 \\ 5 & .217299 \mathrm{E}-02 & -.570809 \mathrm{E}-01 & .181895 \mathrm{E}-02 \\ 6 & .536989 \mathrm{E}-03 & -.539297 \mathrm{E}-01 & -.111040 \mathrm{E}-03 \\ 7 & .130017 \mathrm{E}-03 & -.524747 \mathrm{E}-01 & -.846737 \mathrm{E}-03 \\ 8 & .361130 \mathrm{E}-03 & -.595121 \mathrm{E}-01 & .250278 \mathrm{E}-03 \\ 12 & .463250 \mathrm{E}-04 & -.640373 \mathrm{E}-01 & .107151 \mathrm{E}-03 \\ 16 & -.342733 \mathrm{E}-04 & -.641007 \mathrm{E}-01 & .580690 \mathrm{E}-04 \\ 20 & .867362 \mathrm{E}-18 & -.629970 \mathrm{E}-01 & .485426 \mathrm{E}-04\end{array}$

US-GERMAN IMPULSE RESPONSES TO SUPPLY SHOCK

$\begin{array}{rccc} & \mathrm{y}_{\mathrm{t}} & \mathrm{q}_{\mathrm{t}} & \pi_{\mathrm{t}} \\ 1 & .107366 \mathrm{E}-01 & -.469937 \mathrm{E}-02 & -.302216 \mathrm{E}-02 \\ 2 & .100153 \mathrm{E}-01 & -.141524 \mathrm{E}-01 & -.325668 \mathrm{E}-03 \\ 3 & .108198 \mathrm{E}-01 & -.203115 \mathrm{E}-01 & .385827 \mathrm{E}-04 \\ 4 & .118282 \mathrm{E}-01 & -.173231 \mathrm{E}-01 & -.325452 \mathrm{E}-03 \\ 5 & .143074 \mathrm{E}-01 & -.491096 \mathrm{E}-02 & -.126214 \mathrm{E}-02 \\ 6 & .142004 \mathrm{E}-01 & -.943079 \mathrm{E}-02 & -.244555 \mathrm{E}-04 \\ 7 & .147608 \mathrm{E}-01 & -.123987 \mathrm{E}-01 & .277859 \mathrm{E}-03 \\ 8 & .153606 \mathrm{E}-01 & -.648407 \mathrm{E}-02 & -.140733 \mathrm{E}-03 \\ 12 & .164576 \mathrm{E}-01 & -.152274 \mathrm{E}-02 & .377159 \mathrm{E}-05 \\ 16 & .167040 \mathrm{E}-01 & -.128286 \mathrm{E}-02 & .374282 \mathrm{E}-04 \\ 20 & .166738 \mathrm{E}-01 & -.256879 \mathrm{E}-02 & .202379 \mathrm{E}-04\end{array}$


TABLE 6

\begin{tabular}{|c|c|c|c|}
\hline & US - JAPAN & RESPONSES TO & MONETARY SHOCK \\
\hline 1 & $\begin{array}{c}y_{t} \\
.565697 E-02\end{array}$ & $\begin{array}{c}q_{t} \\
.335221 E-01\end{array}$ & $\begin{array}{c}\pi_{\mathrm{t}} \\
.336510 \mathrm{E}-02\end{array}$ \\
\hline 2 & $.725507 \mathrm{E}-02$ & $.376019 E-01$ & $-.115308 E-02$ \\
\hline 3 & $.617822 \mathrm{E}-02$ & $.393904 E-01$ & $.277211 \mathrm{E}-02$ \\
\hline 4 & $.710464 E-02$ & $.366256 \mathrm{E}-01$ & $.115327 E-02$ \\
\hline 5 & $.518038 \mathrm{E}-02$ & $.262617 \mathrm{E}-01$ & $.255423 \mathrm{E}-02$ \\
\hline 6 & $.411260 \mathrm{E}-02$ & $.226716 \mathrm{E}-01$ & $-.129827 E-03$ \\
\hline 7 & $.315616 \mathrm{E}-02$ & $.199404 \mathrm{E}-01$ & $.200962 E-02$ \\
\hline 8 & $261808 \mathrm{E}-02$ & $.126687 \mathrm{E}-01$ & $.124556 \mathrm{E}-06$ \\
\hline 12 & $.469491 \mathrm{E}-03$ & $.209572 \mathrm{E}-02$ & $-.423653 \mathrm{E}-03$ \\
\hline 16 & $.159367 \mathrm{E}-04$ & $-.639773 \mathrm{E}-05$ & $-.378485 E-03$ \\
\hline 20 & $-.582759 E-18$ & $-.542101 \mathrm{E}-18$ & $-.261581 \mathrm{E}-03$ \\
\hline
\end{tabular}

US - JAPAN RESPONSES TO DEMAND SHOCK

$\begin{array}{rrrr} & \mathrm{y}_{\mathrm{t}} & \mathrm{q}_{\mathrm{t}} & \pi_{\mathrm{t}} \\ 1 & .360980 \mathrm{E}-02 & -.444275 \mathrm{E}-01 & .431648 \mathrm{E}-02 \\ 2 & .968059 \mathrm{E}-03 & -.558781 \mathrm{E}-01 & -.146771 \mathrm{E}-02 \\ 3 & -.663965 \mathrm{E}-04 & -.506337 \mathrm{E}-01 & .431040 \mathrm{E}-03 \\ 4 & .443203 \mathrm{E}-04 & -.501949 \mathrm{E}-01 & -.436735 \mathrm{E}-03 \\ 5 & -.129679 \mathrm{E}-02 & -.650335 \mathrm{E}-01 & .720145 \mathrm{E}-03 \\ 6 & -.174177 \mathrm{E}-02 & -.644940 \mathrm{E}-01 & -.108157 \mathrm{E}-02 \\ 7 & -.144962 \mathrm{E}-02 & -.609554 \mathrm{E}-01 & .167099 \mathrm{E}-03 \\ 8 & -.114340 \mathrm{E}-02 & -.610114 \mathrm{E}-01 & -.796735 \mathrm{E}-03 \\ 12 & -.464446 \mathrm{E}-03 & -.573463 \mathrm{E}-01 & -.466567 \mathrm{E}-03 \\ 16 & -.775631 \mathrm{E}-04 & -.551524 \mathrm{E}-01 & -.229815 \mathrm{E}-03 \\ 20 & .203288 \mathrm{E}-17 & -.546982 \mathrm{E}-01 & -.130661 \mathrm{E}-03\end{array}$

US-JAPAN RESPONSES TO SUPPLY SHOCK

\begin{tabular}{ccr}
$\mathrm{y}_{\mathrm{t}}$ & \multicolumn{1}{c}{$\mathrm{q}_{\mathrm{t}}$} & \multicolumn{1}{c}{$\pi_{\mathrm{t}}$} \\
$.559077 \mathrm{E}-02$ & $-.537368 \mathrm{E}-02$ & $-.384005 \mathrm{E}-02$ \\
$.741437 \mathrm{E}-02$ & $.266448 \mathrm{E}-02$ & $.121580 \mathrm{E}-02$ \\
$.902411 \mathrm{E}-02$ & $-.938463 \mathrm{E}-03$ & $-.167759 \mathrm{E}-02$ \\
$.770804 \mathrm{E}-02$ & $.207125 \mathrm{E}-02$ & $.458563 \mathrm{E}-03$ \\
$.861570 \mathrm{E}-02$ & $.509238 \mathrm{E}-02$ & $-.164477 \mathrm{E}-02$ \\
$.842508 \mathrm{E}-02$ & $.477693 \mathrm{E}-02$ & $.100458 \mathrm{E}-02$ \\
$.887824 \mathrm{E}-02$ & $.372161 \mathrm{E}-02$ & $-.136980 \mathrm{E}-02$ \\
$.868503 \mathrm{E}-02$ & $.674140 \mathrm{E}-02$ & $.611680 \mathrm{E}-03$ \\
$.949021 \mathrm{E}-02$ & $.102561 \mathrm{E}-01$ & $.568412 \mathrm{E}-03$ \\
$.972002 \mathrm{E}-02$ & $.111676 \mathrm{E}-01$ & $.418609 \mathrm{E}-03$ \\
$.976482 \mathrm{E}-02$ & $.112756 \mathrm{E}-01$ & $.285706 \mathrm{E}-03$
\end{tabular}


TABLE 7

US-UK RESPONSES TO MONETARY SHOCK

$\begin{array}{cccc} & \mathrm{y}_{\mathrm{t}} & \mathrm{q}_{\mathrm{t}} & \pi_{\mathrm{t}} \\ 1 & .480840 \mathrm{E}-02 & .770488 \mathrm{E}-02 & .997369 \mathrm{E}-02 \\ 2 & .316609 \mathrm{E}-02 & .752780 \mathrm{E}-02 & .300897 \mathrm{E}-02 \\ 3 & .136282 \mathrm{E}-02 & .739711 \mathrm{E}-02 & .155882 \mathrm{E}-02 \\ 4 & .291676 \mathrm{E}-02 & .250731 \mathrm{E}-02 & .996563 \mathrm{E}-03 \\ 5 & .143993 \mathrm{E}-02 & .153664 \mathrm{E}-02 & .567977 \mathrm{E}-02 \\ 6 & .110654 \mathrm{E}-02 & .419841 \mathrm{E}-02 & .135606 \mathrm{E}-02 \\ 7 & .535341 \mathrm{E}-03 & .325089 \mathrm{E}-02 & .970166 \mathrm{E}-03 \\ 8 & .122096 \mathrm{E}-02 & .220912 \mathrm{E}-02 & .836404 \mathrm{E}-03 \\ 12 & .486967 \mathrm{E}-03 & .927409 \mathrm{E}-03 & .593700 \mathrm{E}-03 \\ 16 & .163451 \mathrm{E}-03 & .329292 \mathrm{E}-03 & .344739 \mathrm{E}-03 \\ 20 & .765718 \mathrm{E}-18 & .116552 \mathrm{E}-17 & .188594 \mathrm{E}-03\end{array}$

US-UK RESPONSES TO DEMAND SHOCK

$\begin{array}{rrrr} & \mathrm{y}_{\mathrm{t}} & \mathrm{q}_{\mathrm{t}} & \pi_{\mathrm{t}} \\ 1 & .229197 \mathrm{E}-02 & -.507965 \mathrm{E}-01 & .273261 \mathrm{E}-02 \\ 2 & -.118378 \mathrm{E}-02 & -.642504 \mathrm{E}-01 & -.101441 \mathrm{E}-02 \\ 3 & -.880526 \mathrm{E}-03 & -.515051 \mathrm{E}-01 & -.199063 \mathrm{E}-02 \\ 4 & .371340 \mathrm{E}-03 & -.608221 \mathrm{E}-01 & -.732438 \mathrm{E}-03 \\ 5 & -.309913 \mathrm{E}-03 & -.676993 \mathrm{E}-01 & .204373 \mathrm{E}-02 \\ 6 & -.352178 \mathrm{E}-03 & -.637147 \mathrm{E}-01 & -.112332 \mathrm{E}-02 \\ 7 & -.425907 \mathrm{E}-03 & -.631625 \mathrm{E}-01 & -.105984 \mathrm{E}-02 \\ 8 & .230455 \mathrm{E}-03 & -.660344 \mathrm{E}-01 & -.192811 \mathrm{E}-03 \\ 12 & .615816 \mathrm{E}-04 & -.659630 \mathrm{E}-01 & -.105889 \mathrm{E}-04 \\ 16 & .142818 \mathrm{E}-04 & -.656586 \mathrm{E}-01 & .675603 \mathrm{E}-05 \\ 20 & -.711508 \mathrm{E}-19 & -.655296 \mathrm{E}-01 & .391420 \mathrm{E}-06\end{array}$

US-UK RESPONSES TO SUPPLY SHOCK

$\begin{array}{rccc} & \mathrm{y}_{\mathrm{t}} & \mathrm{q}_{\mathrm{t}} & \pi_{\mathrm{t}} \\ 1 & .120754 \mathrm{E}-01 & .365298 \mathrm{E}-02 & -.545602 \mathrm{E}-02 \\ 2 & .107728 \mathrm{E}-01 & -.317862 \mathrm{E}-02 & .116221 \mathrm{E}-02 \\ 3 & .106590 \mathrm{E}-01 & -.100057 \mathrm{E}-01 & .327326 \mathrm{E}-03 \\ 4 & .873475 \mathrm{E}-02 & -.186158 \mathrm{E}-01 & .212230 \mathrm{E}-02 \\ 5 & .797912 \mathrm{E}-02 & -.147364 \mathrm{E}-01 & .436523 \mathrm{E}-03 \\ 6 & .827197 \mathrm{E}-02 & -.121161 \mathrm{E}-01 & .831237 \mathrm{E}-04 \\ 7 & .871312 \mathrm{E}-02 & -.135824 \mathrm{E}-01 & -.397546 \mathrm{E}-04 \\ 8 & .873188 \mathrm{E}-02 & -.142033 \mathrm{E}-01 & .542297 \mathrm{E}-03 \\ 12 & .848528 \mathrm{E}-02 & -.144911 \mathrm{E}-01 & .268959 \mathrm{E}-03 \\ 16 & .847076 \mathrm{E}-02 & -.145488 \mathrm{E}-01 & .114085 \mathrm{E}-03 \\ 20 & .844958 \mathrm{E}-02 & -.146026 \mathrm{E}-01 & .480230 \mathrm{E}-04\end{array}$


TABLE 8

US-CANADIAN RESPONSES TO MONETARY SHOCK

$\begin{array}{cccc} & \mathrm{y}_{\mathrm{t}} & \mathrm{q}_{\mathrm{t}} & \pi_{\mathrm{t}} \\ 1 & .4 / 1092 \mathrm{E}-02 & .182870 \mathrm{E}-02 & .429534 \mathrm{E}-02 \\ 2 & .294203 \mathrm{E}-02 & .238302 \mathrm{E}-02 & .309247 \mathrm{E}-03 \\ 3 & .272456 \mathrm{E}-02 & .876194 \mathrm{E}-03 & .205816 \mathrm{E}-02 \\ 4 & .340201 \mathrm{E}-02 & .285330 \mathrm{E}-03 & .358478 \mathrm{E}-03 \\ 5 & .219198 \mathrm{E}-02 & .226414 \mathrm{E}-02 & .135889 \mathrm{E}-02 \\ 6 & .16784 / \mathrm{E}-02 & .809220 \mathrm{E}-03 & .579037 \mathrm{E}-03 \\ 7 & .130699 \mathrm{E}-02 & .115878 \mathrm{E}-02 & .534917 \mathrm{E}-03 \\ 8 & .119915 \mathrm{E}-02 & .153429 \mathrm{E}-02 & .379123 \mathrm{E}-03 \\ 17 & .254091 \mathrm{E}-03 & .274256 \mathrm{E}-03 & .846000 \mathrm{E}-04 \\ 16 & .331907 \mathrm{E}-04 & .926501 \mathrm{~F}-04 & -.367252 \mathrm{E}-05 \\ 20 & -.128241 \mathrm{E}-17 & .372694 \mathrm{E}-18 & -.111083 \mathrm{E}-04\end{array}$

US-CANADIAN RESPONSES TO DEMAND SHOCK

$\begin{array}{ccc}\mathrm{y}_{\mathrm{t}} & \mathrm{q}_{\mathrm{t}} & \pi_{\mathrm{t}} \\ .122717 \mathrm{E}-02 & -.210094 \mathrm{E}-01 & .315369 \mathrm{E}-02 \\ .226703 \mathrm{E}-02 & -.199714 \mathrm{E}-01 & -.103200 \mathrm{E}-02 \\ .901374 \mathrm{E}-03 & -.223527 \mathrm{E}-01 & .605525 \mathrm{E}-03 \\ .586189 \mathrm{E}-03 & -.281629 \mathrm{E}-01 & -.714914 \mathrm{E}-03 \\ .471416 \mathrm{E}-04 & -.233444 \mathrm{E}-01 & .241460 \mathrm{E}-04 \\ -.468162 \mathrm{E}-03 & -.241551 \mathrm{E}-01 & -.131530 \mathrm{E}-03 \\ -.661851 \mathrm{E}-03 & -.251006 \mathrm{E}-01 & -.287491 \mathrm{E}-03 \\ -.219254 \mathrm{E}-03 & -.233682 \mathrm{E}-01 & -.168712 \mathrm{E}-03 \\ -.202241 \mathrm{E}-03 & -.245108 \mathrm{E}-01 & -.589984 \mathrm{E}-04 \\ -.479572 \mathrm{E}-04 & -.242836 \mathrm{E}-01 & -.214394 \mathrm{E}-04 \\ -.296462 \mathrm{E}-19 & -.242327 \mathrm{E}-01 & -.683498 \mathrm{E}-06\end{array}$

US-CANADIAN RESPONSES TO SUPPLY SHOCK

$y_{t}$

$.633886 \mathrm{E} \cdot 02$ $660256 \mathrm{E}-02$ $.103325 E-02$ $689749 \mathrm{E}-02$ $.809619 E-02$ $.846144 \mathrm{E}-02$ $867695 \mathrm{E}-02$ $.873178 \mathrm{E}-02$ $.896411 \mathrm{E}-02$ $.88812 / E-02$ $.882778 \mathrm{E}-02$ $\mathbf{q}_{\mathbf{t}}$ $.320999 \mathrm{E}-02$ 103100E-02 $.217623 \mathrm{E}-02$ $.472165 \mathrm{E}-02$ $.511715 E-02$ $.555719 E-02$ $.606427 \mathrm{E}-02$ $.590716 \mathrm{E}-02$ $.650408 \mathrm{E}-02$ $.649608 \mathrm{E}-02$ $.645971 \mathrm{E}-02$ $\pi_{\mathrm{t}}$

$-.421137 \mathrm{E}-02$

$-.926698 \mathrm{E}-03$

$-.399465 \mathrm{E}-03$

$-.141880 \mathrm{E}-03$

$-.299848 \mathrm{E}-03$

- .246906E-03

$119848 \mathrm{E}-03$

$.305629 E-04$ $.646562 \mathrm{E}-04$ $.317945 E-04$ .796776 E-05 
CHART 1
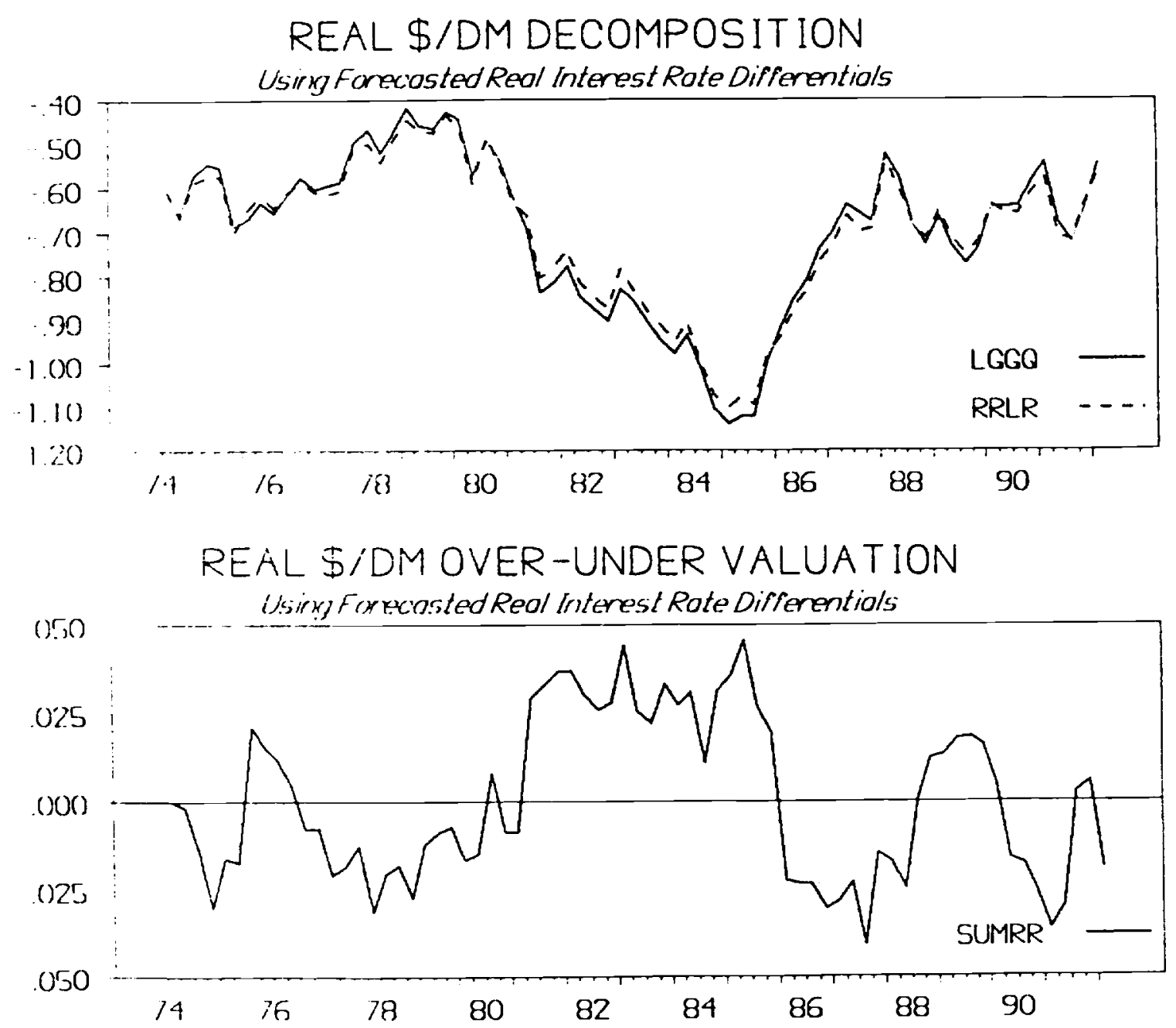

REAL \$/DM OVER-UNDER VALUATION

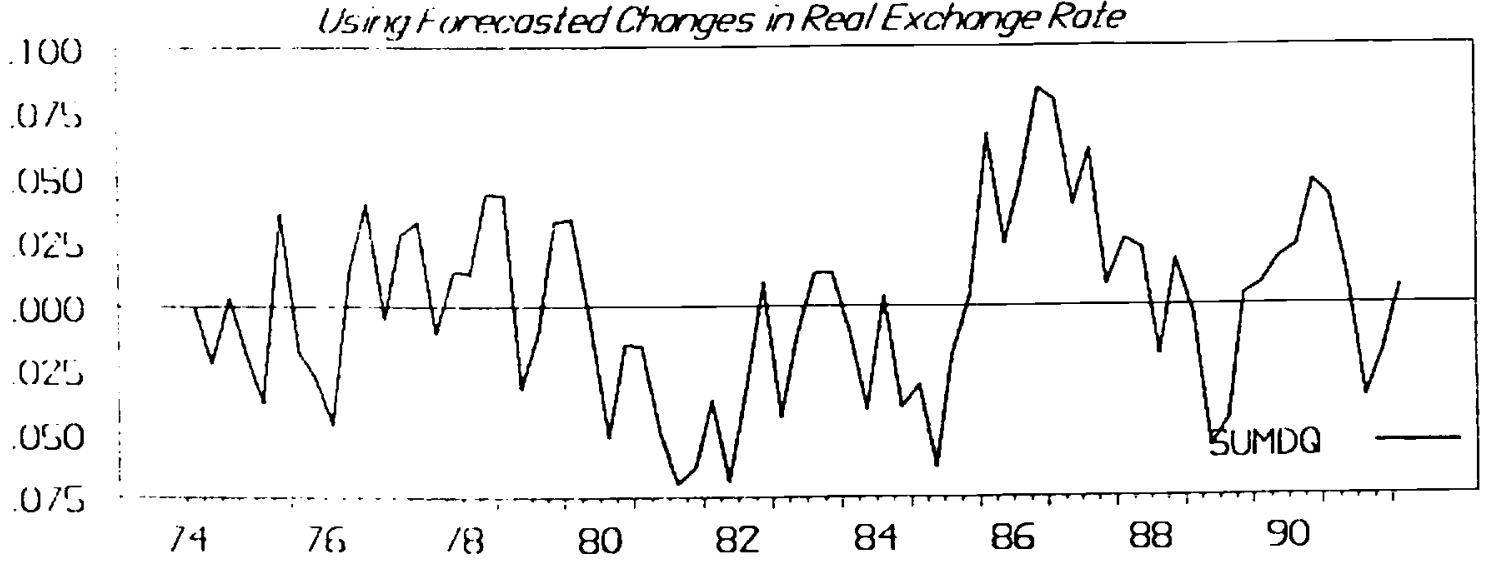


CHART 2

REAL \$/YEN DECOMPOSITION

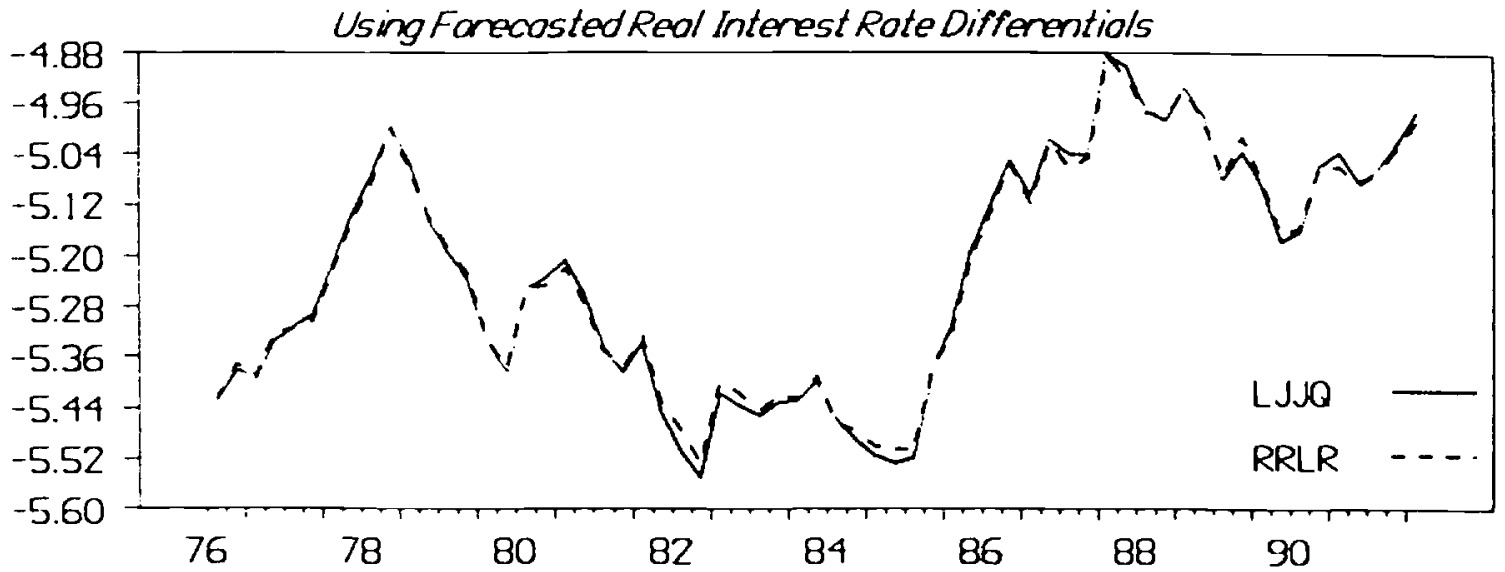

REAL \$/YEN OVER-UNDER VALUATION

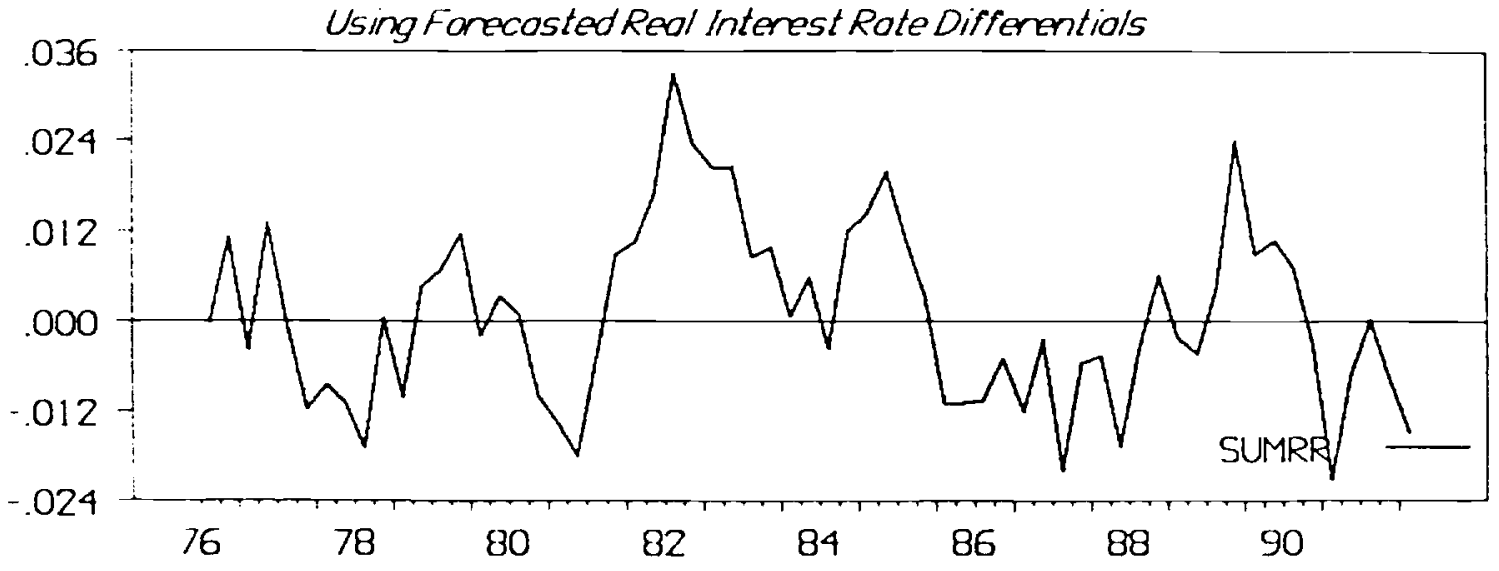

REAL \$/YEN OVER-UNDER VALUATION

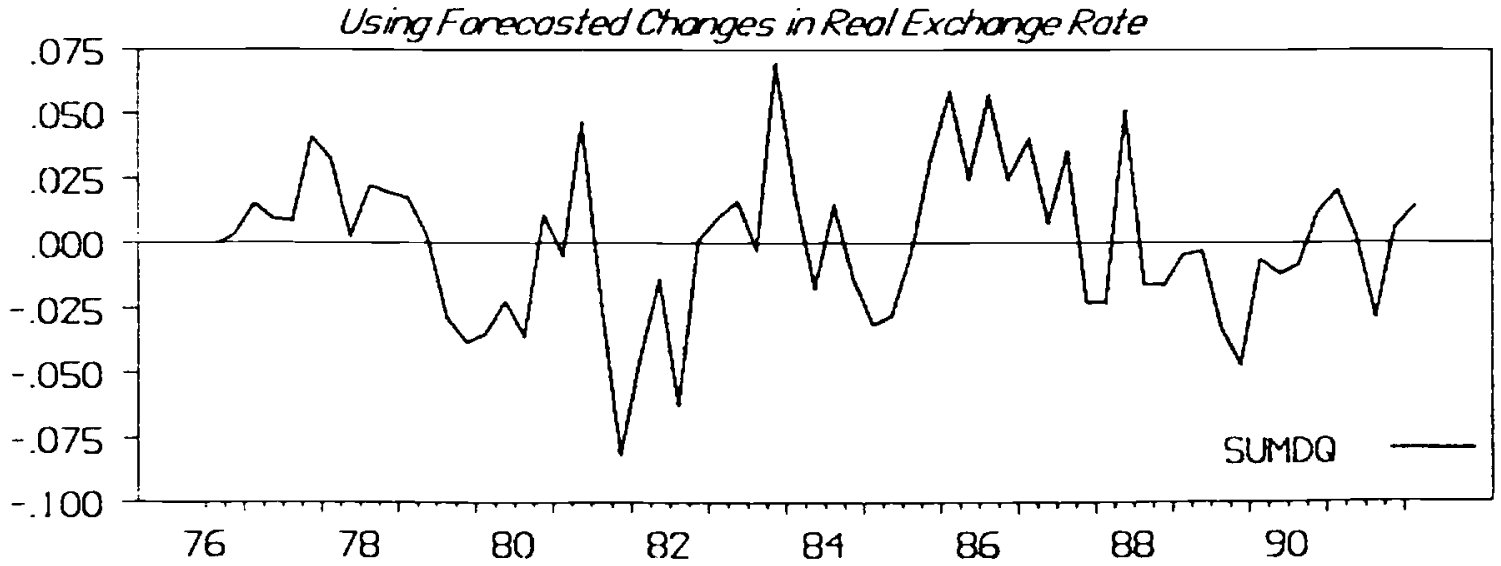


CHART 3

REAL \$/STERLING DECOMPOSITION

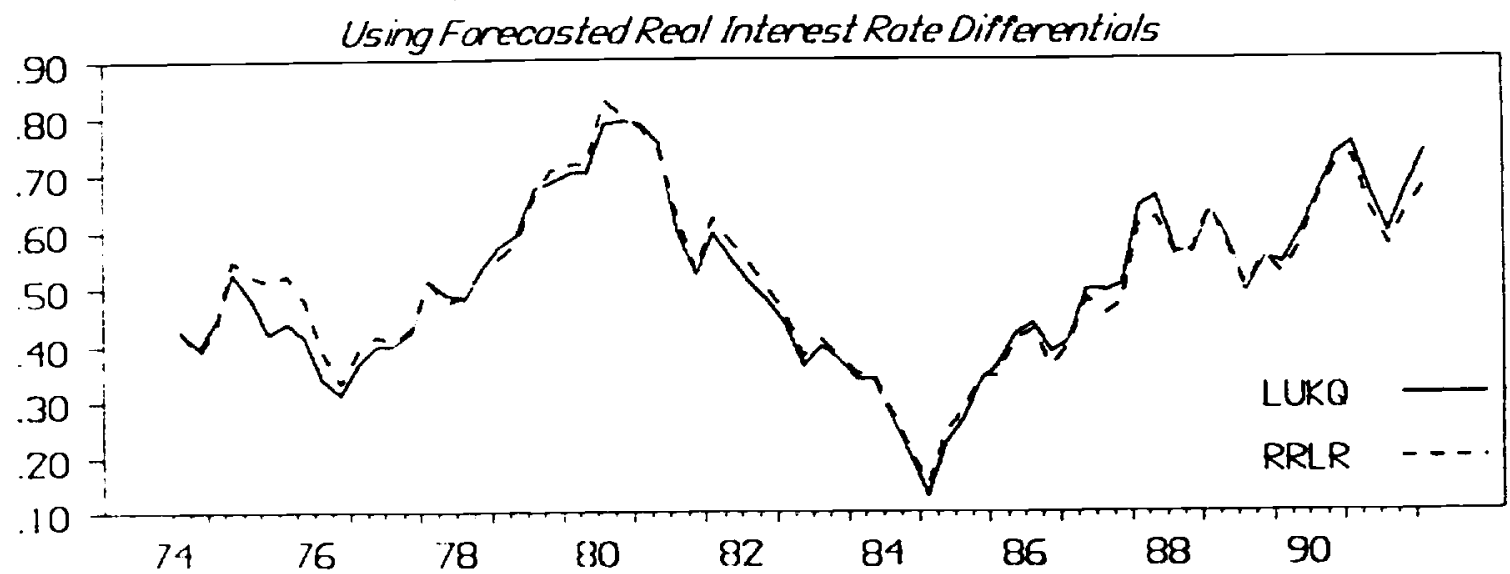

REAL \$/STERLING OVER-UNDER VALUATION Using Fonecosted Rcal Interest Rate Diffenentiols

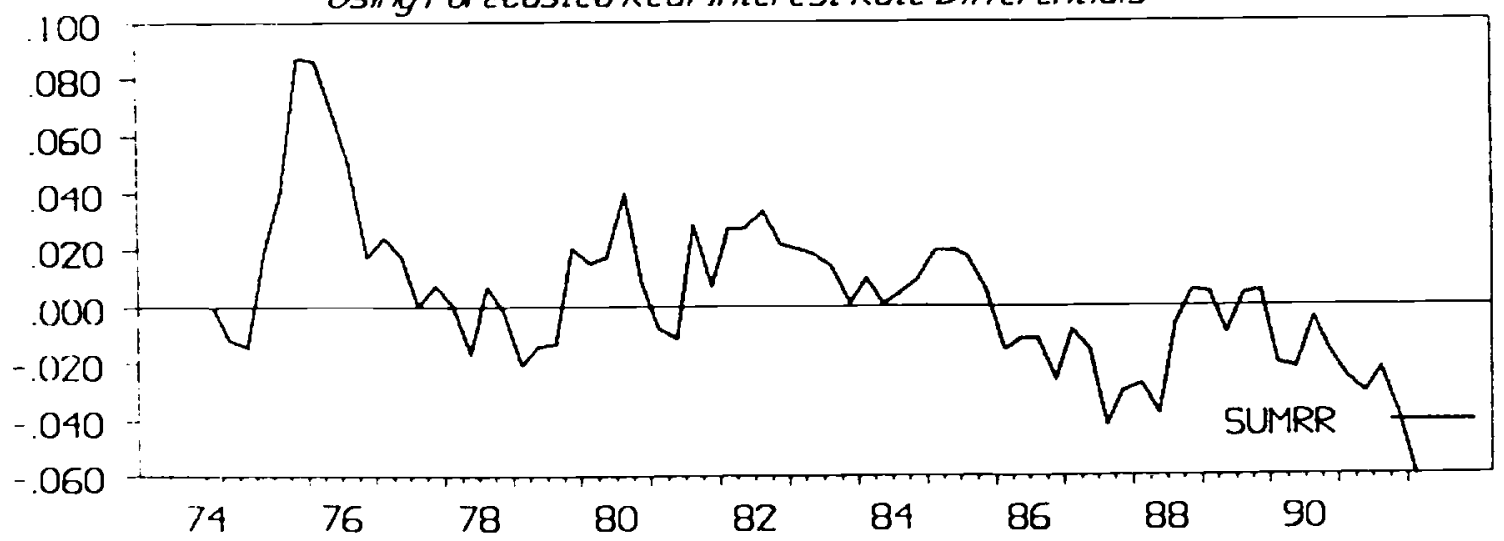

REAL \$/STERLING OVER-UNDER VALUATION

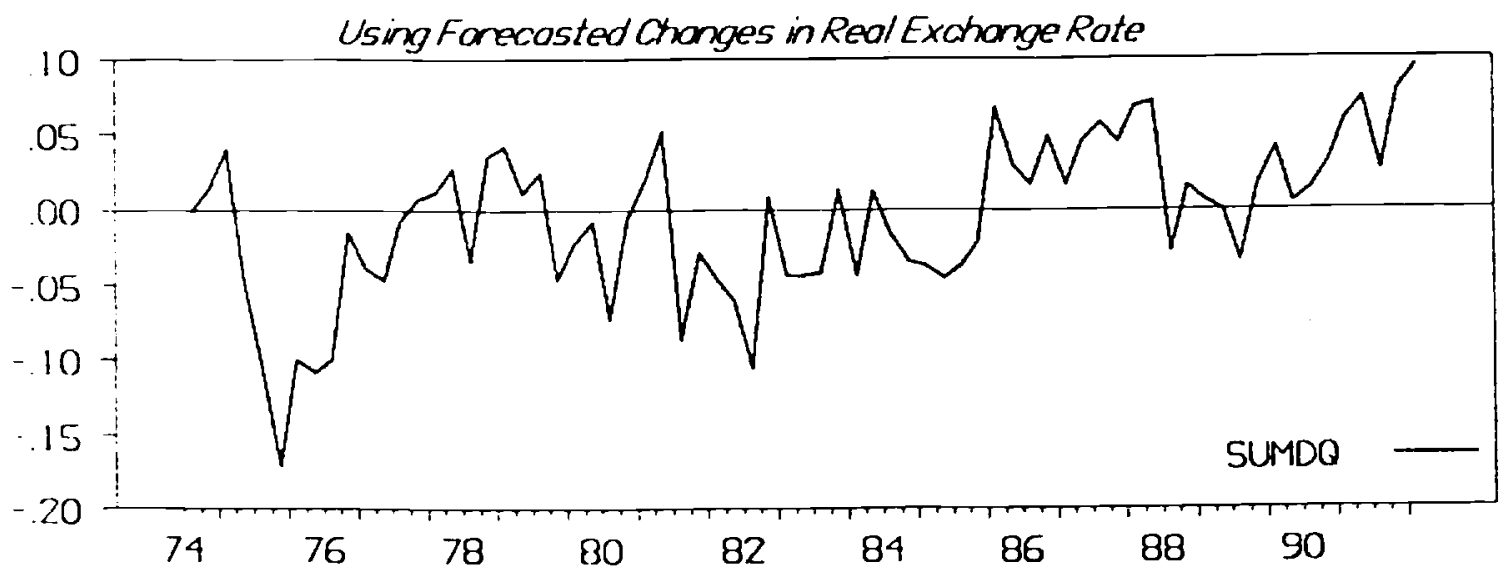



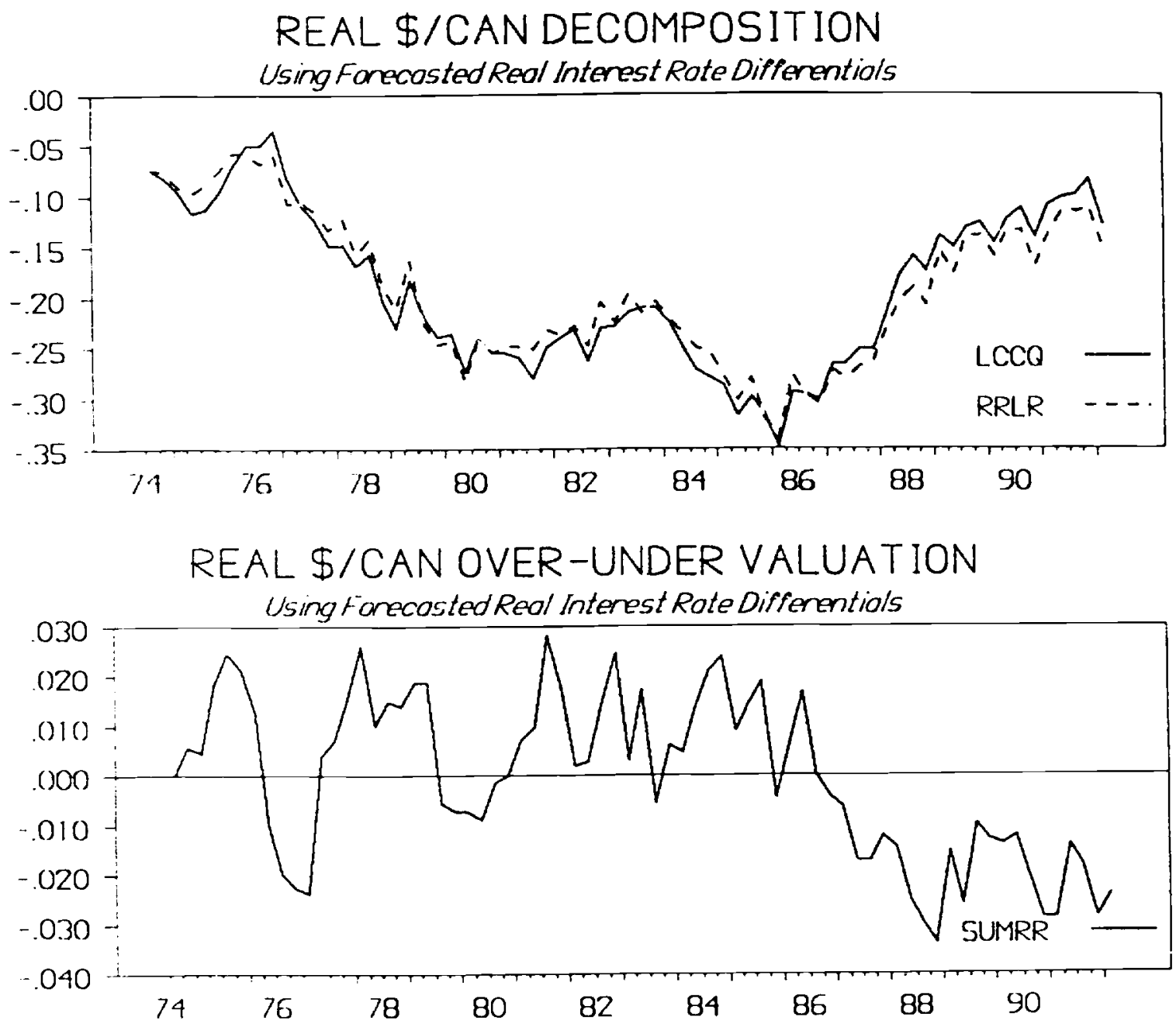

REAL \$/CAN OVER-UNDER VALUATION Using Fonecasted Chonges in Reol Exchange Rate

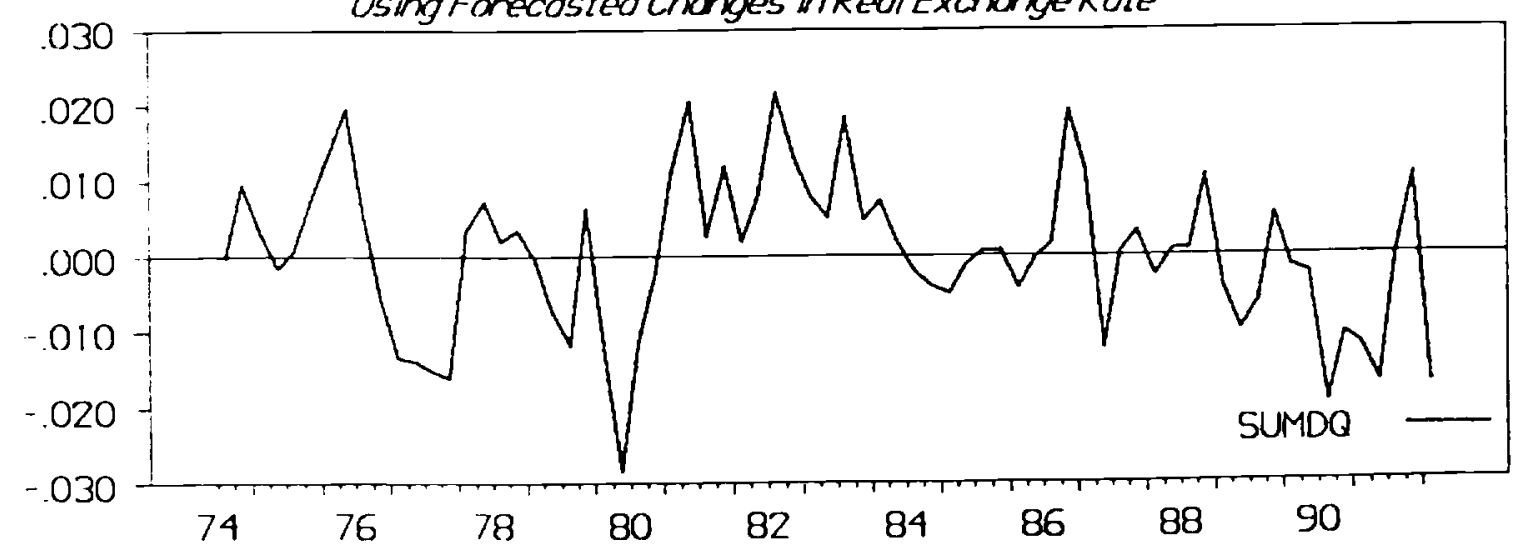


CHART 5

\section{REAL \$/DM BN DECOMPOSITION}

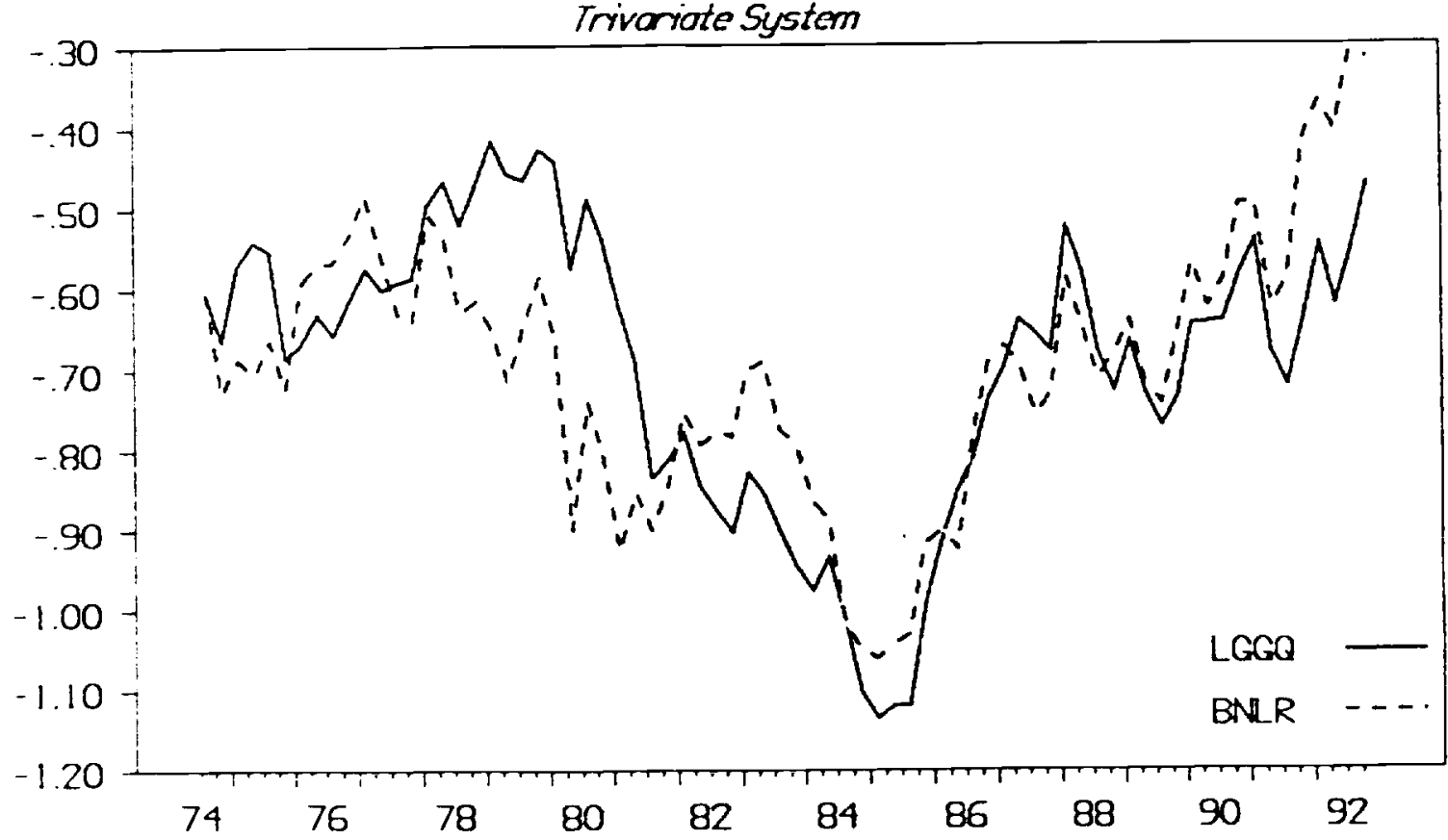

REAL \$/DM OVER-UNDER VALUATION

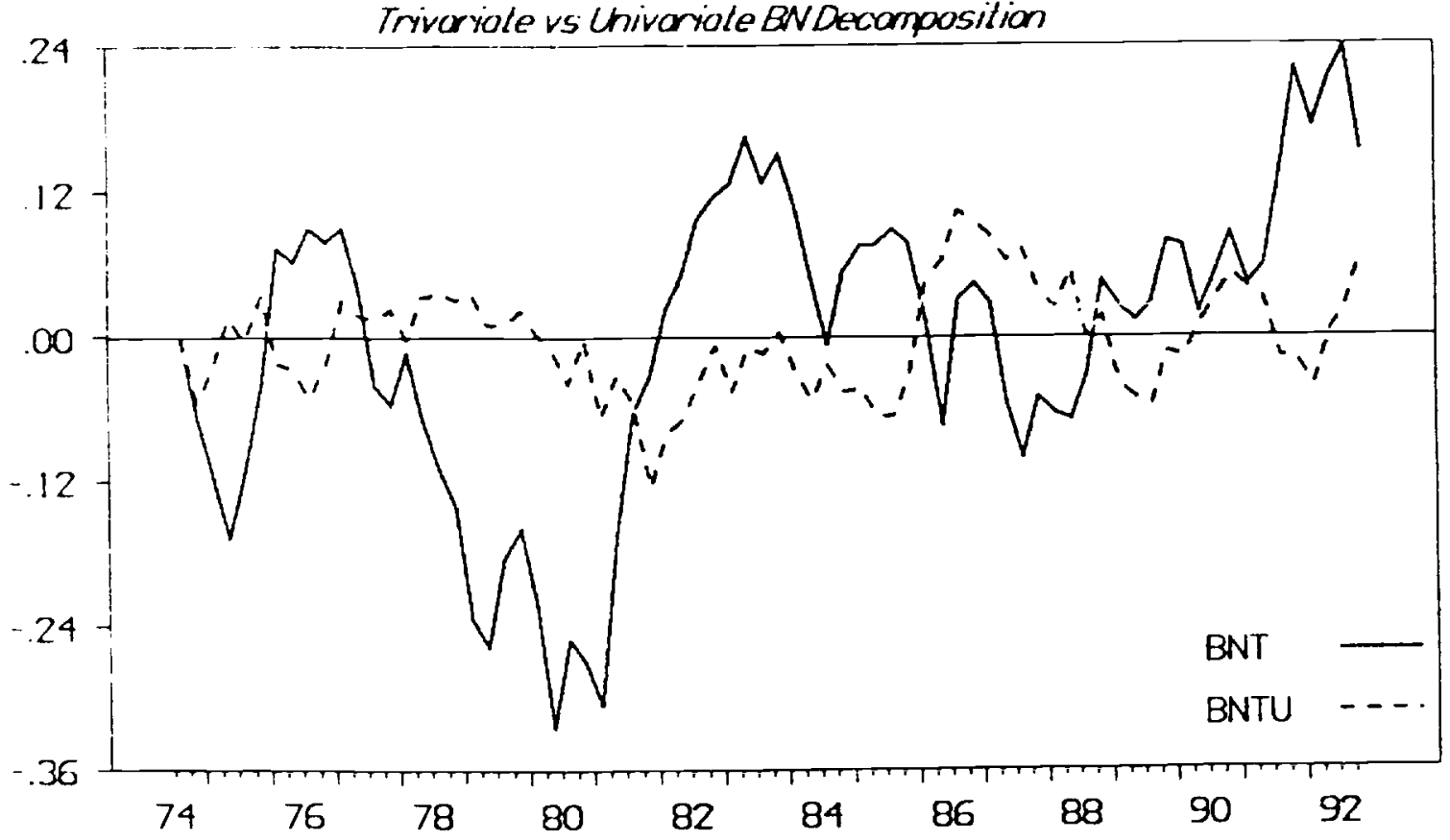


CHART 6

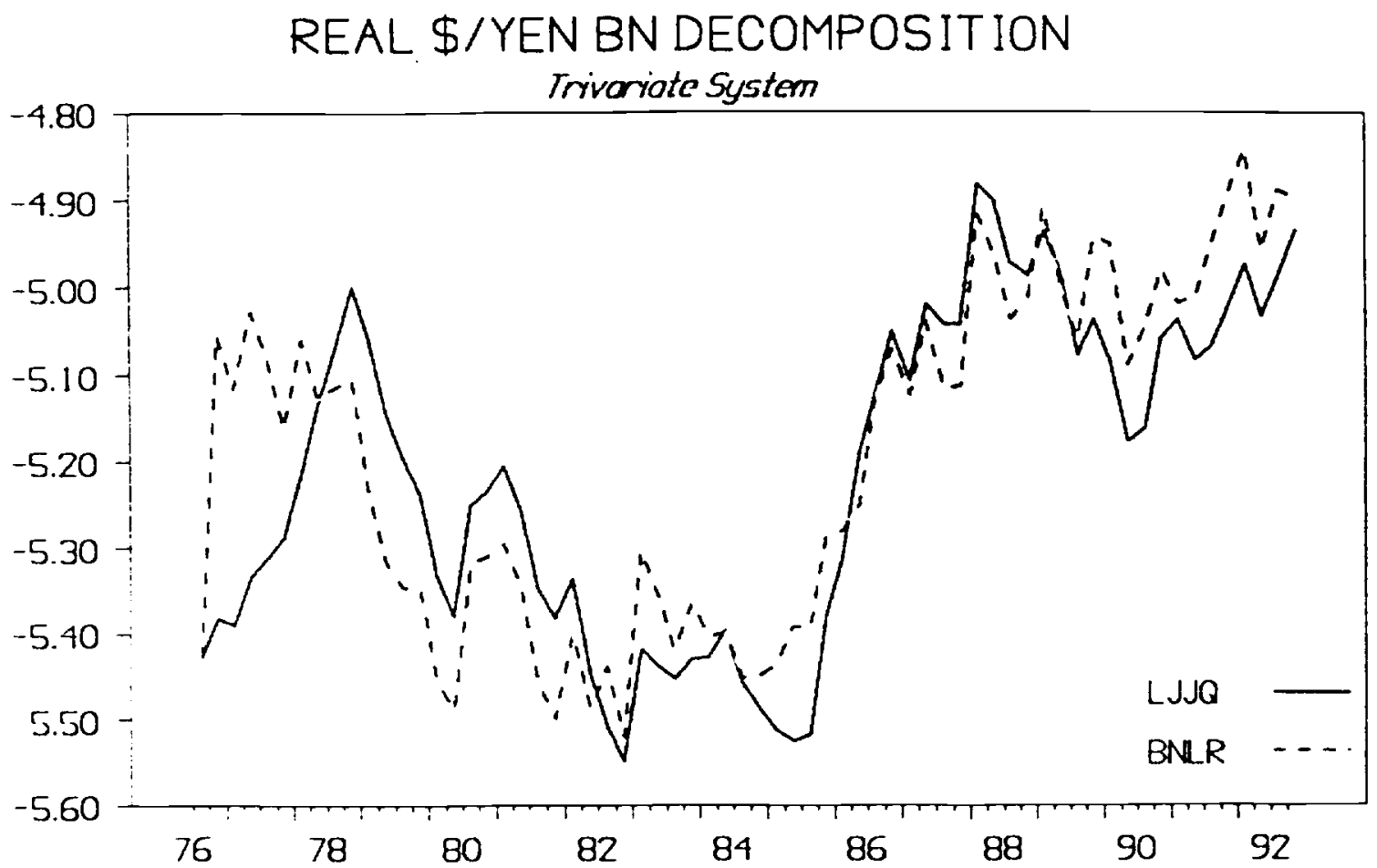

REAL \$/YEN OVER-UNDER VALUATION

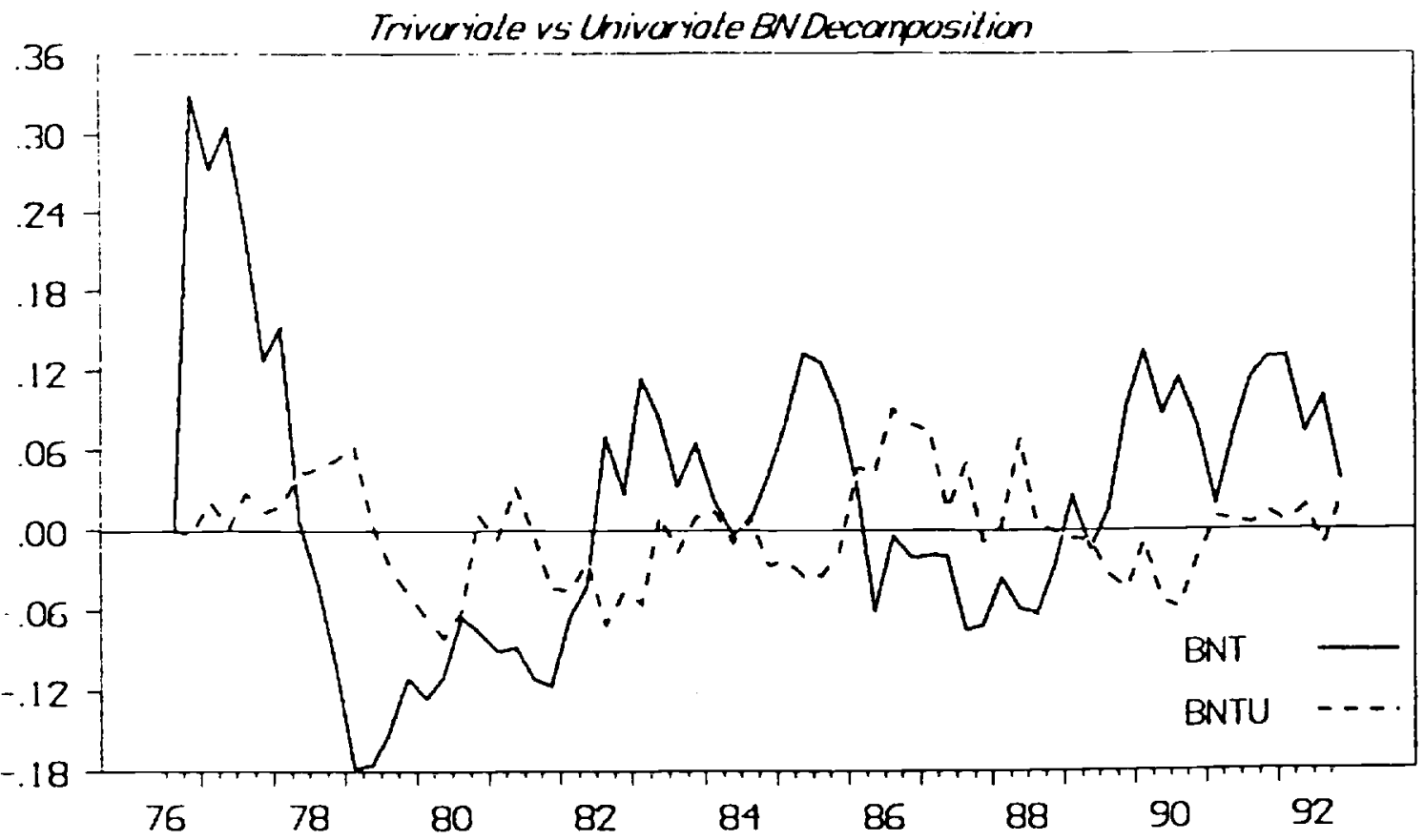


REAL \$/STERLING BN DECOMPOSITION Trivariate Systom

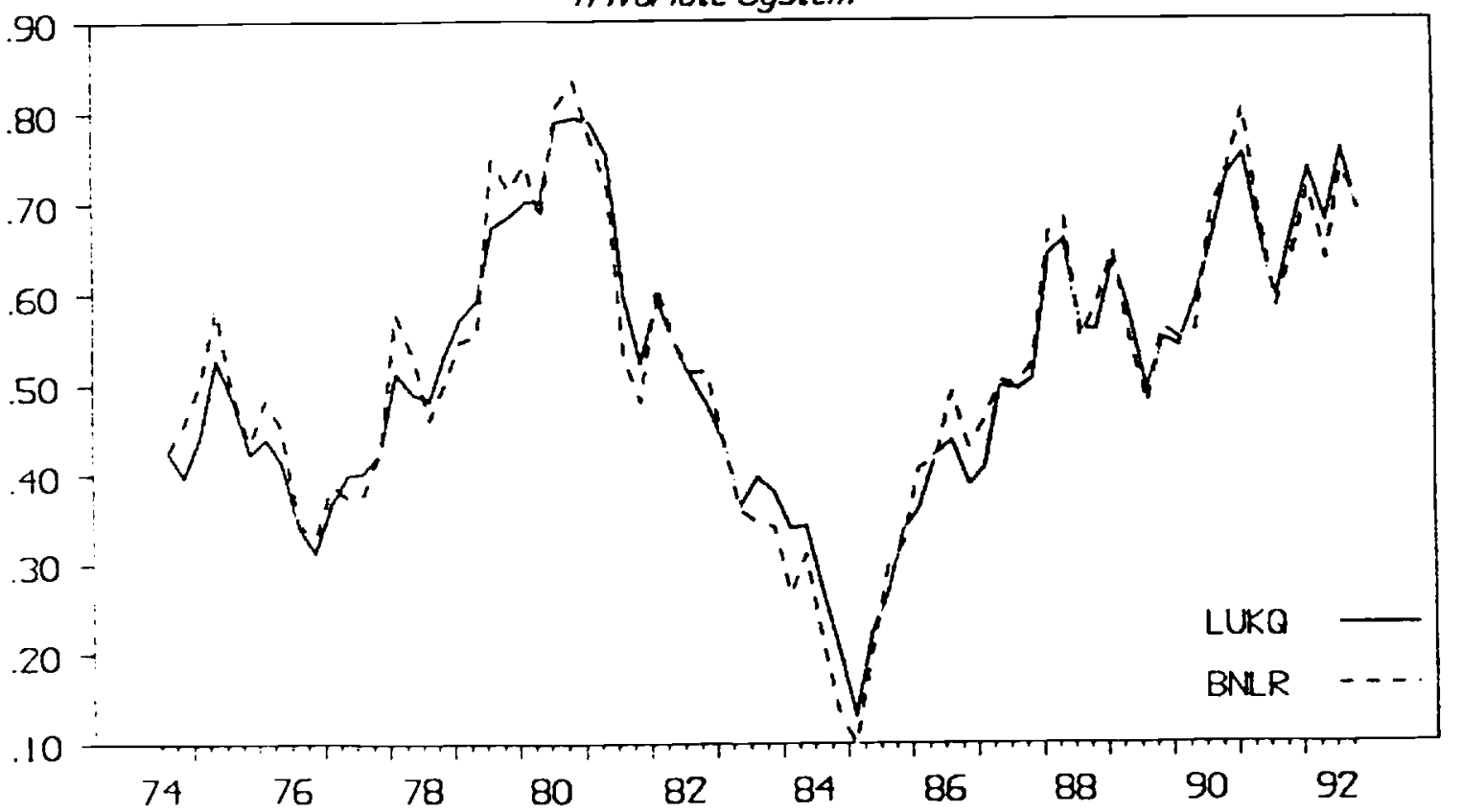

REAL \$/STERLING OVER-UNDER VALUATION

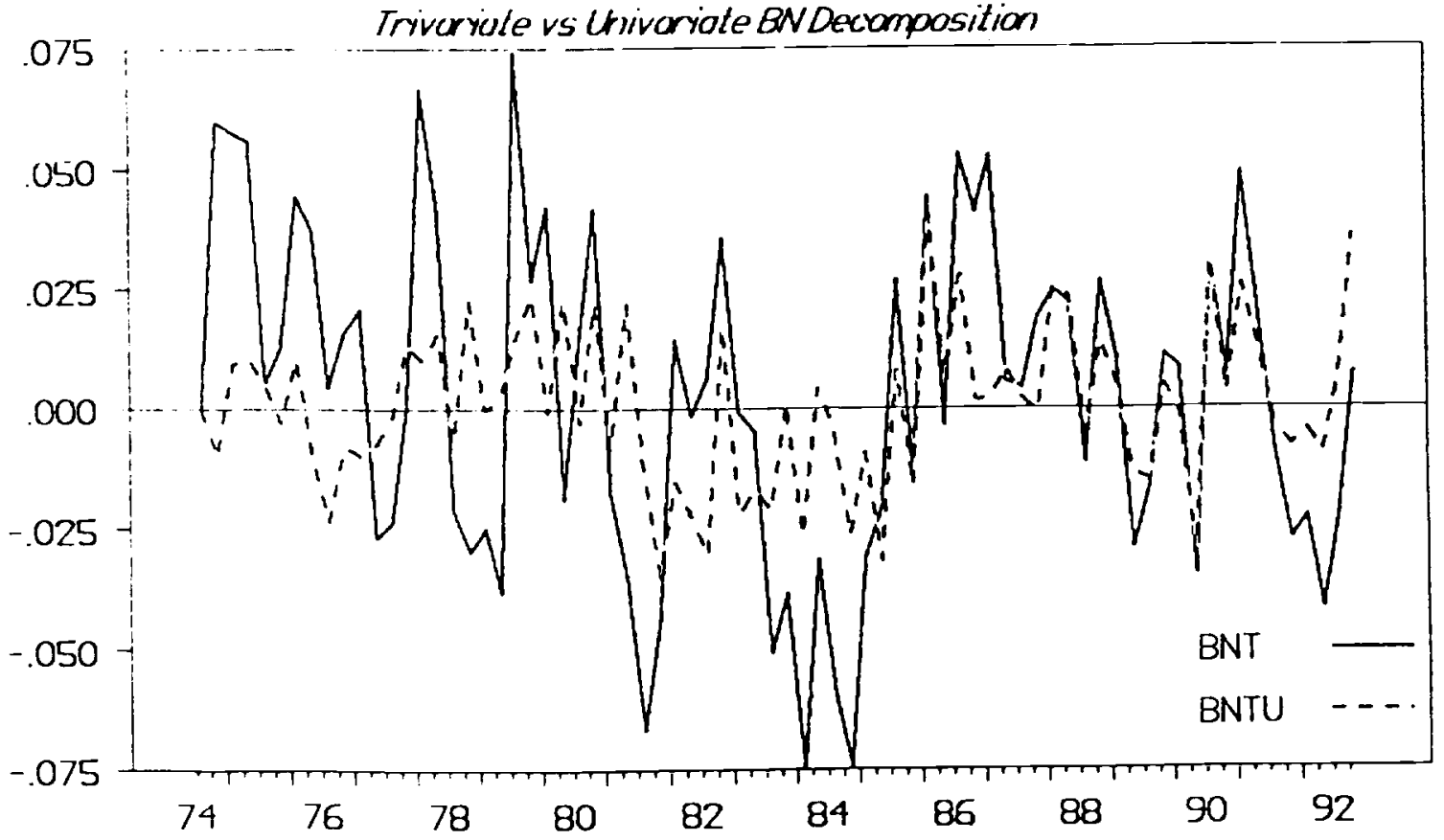


CHART 8
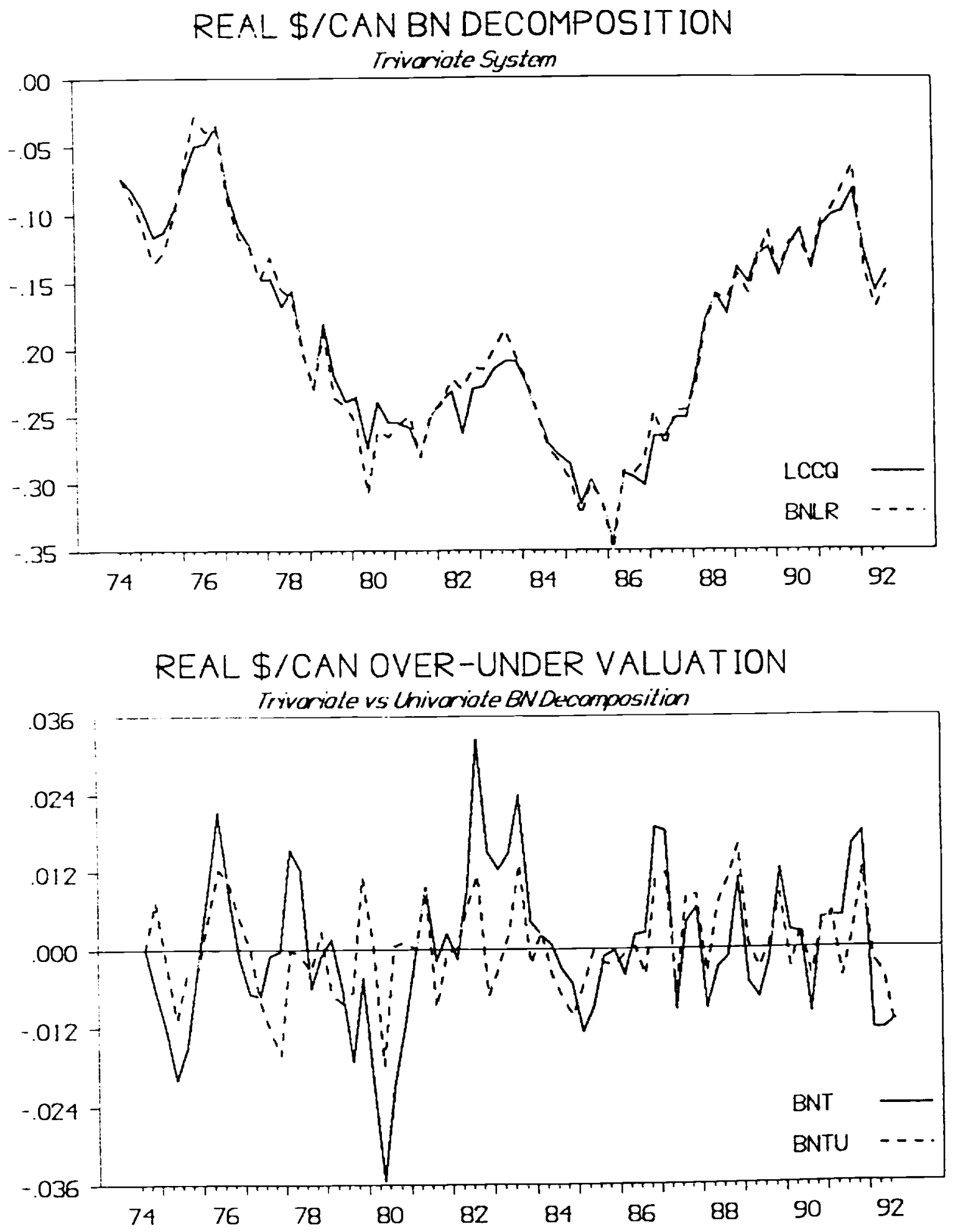
SOURCES OF \$/DM REAL EXCHANGE RATE FLUCTUATIONS
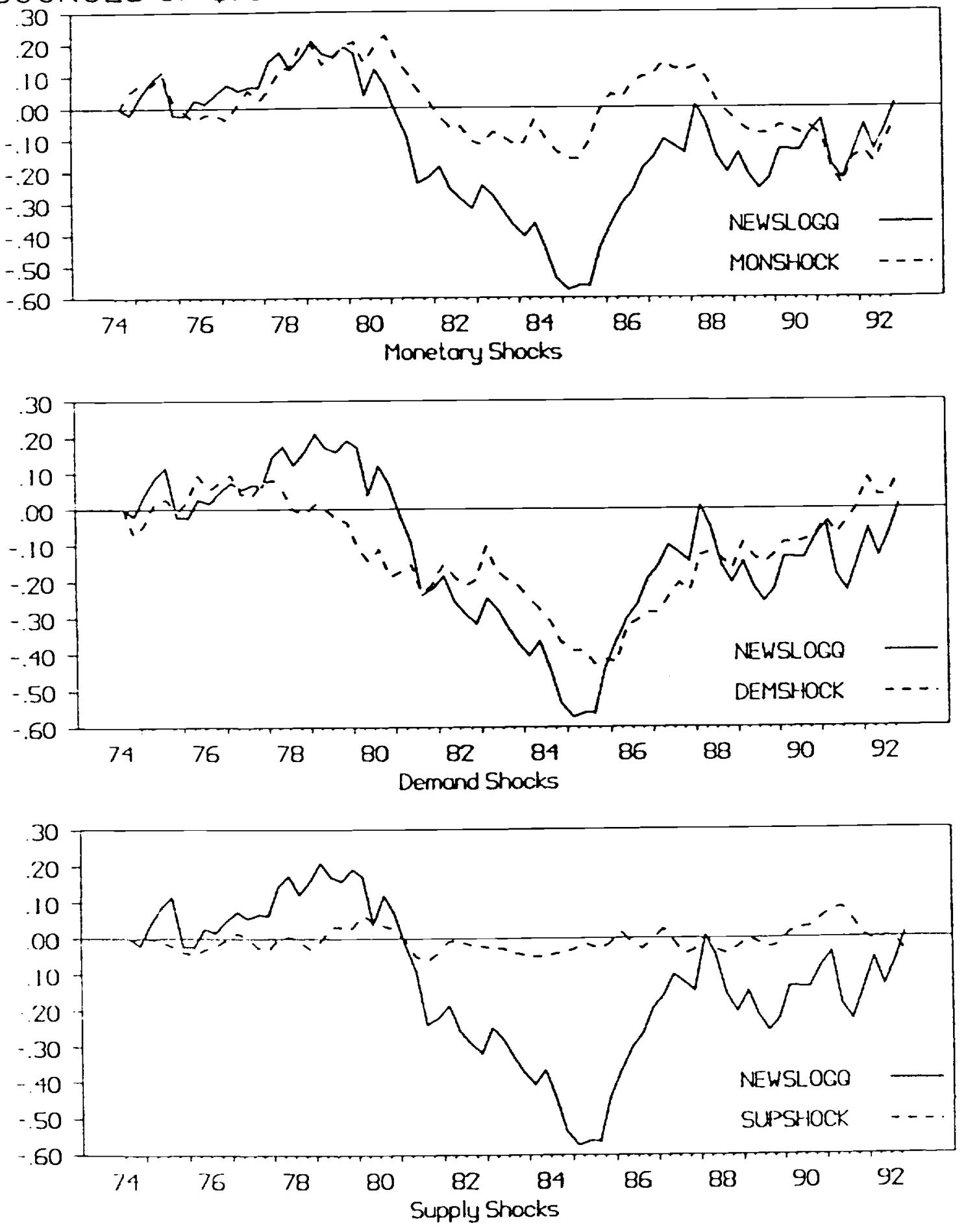
CHART 10

SOURCES OF \$/YEN REAL EXCHANGE RATE FLUCTUATIONS
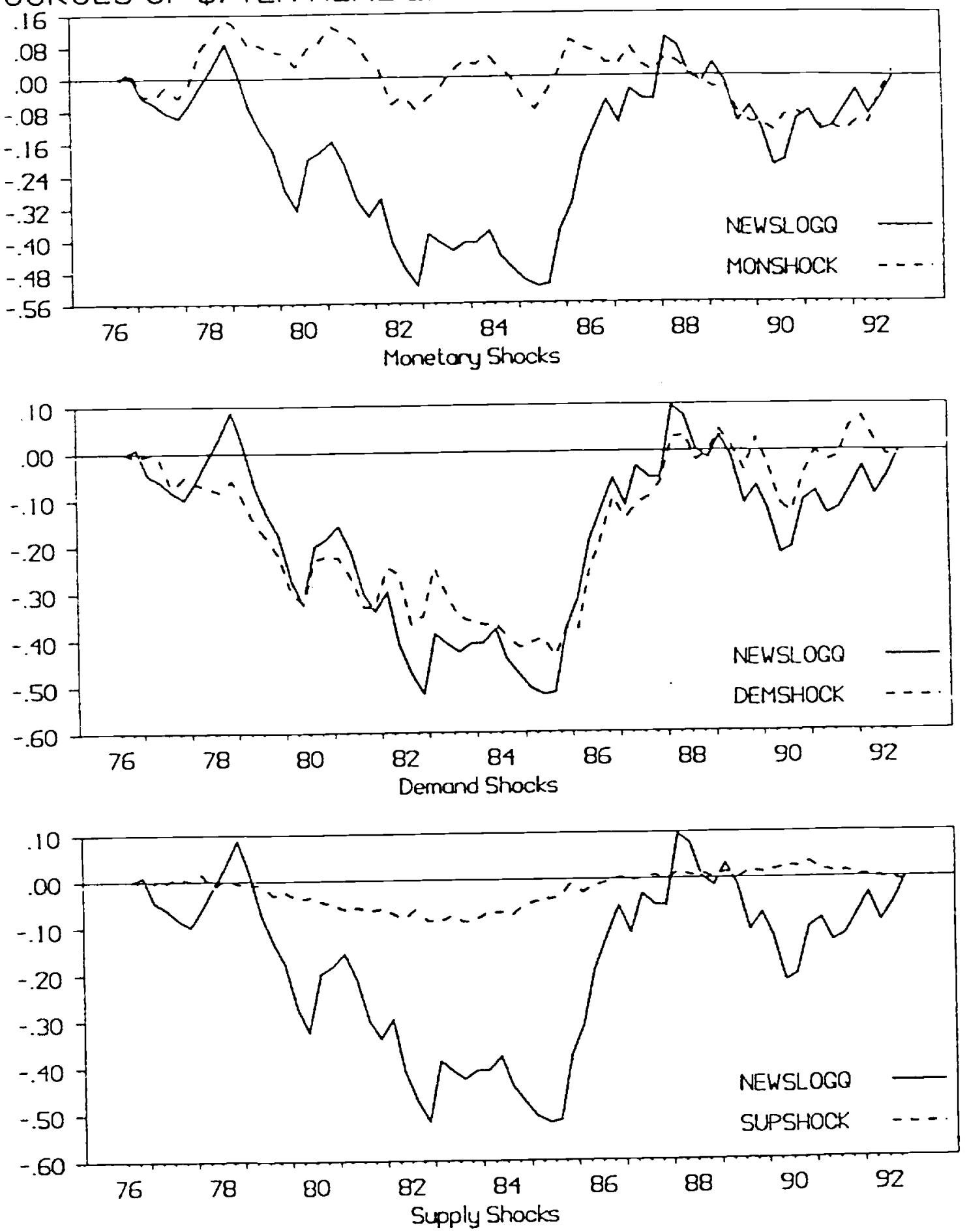
CHART 11

SOURCES \$/STERLING REAL EXCHANGE RATE FLUCTUATIONS
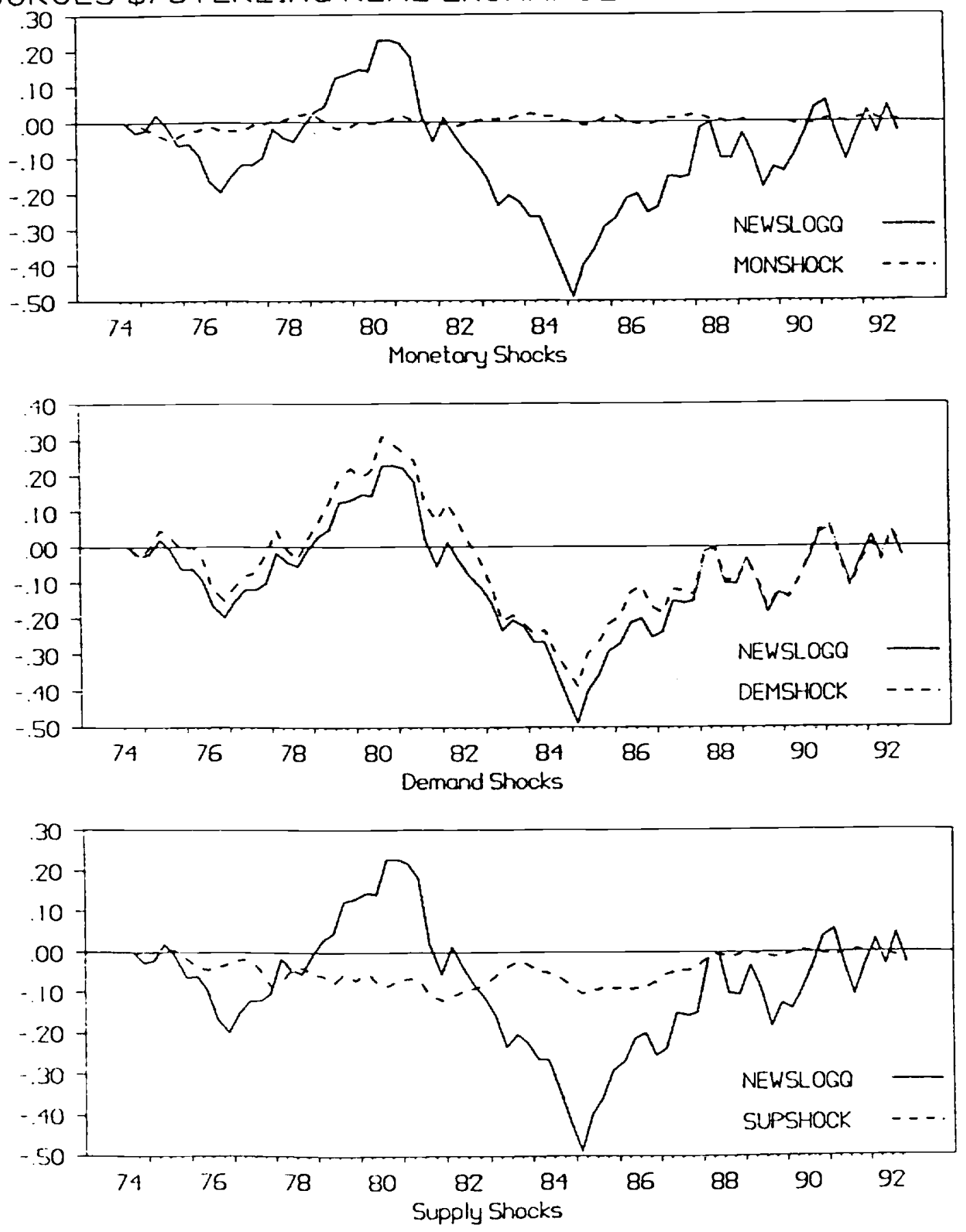
CILART 12

SOURCES OF \$/CAN REAL EXCHANGE RATE FLUCTUATIONS
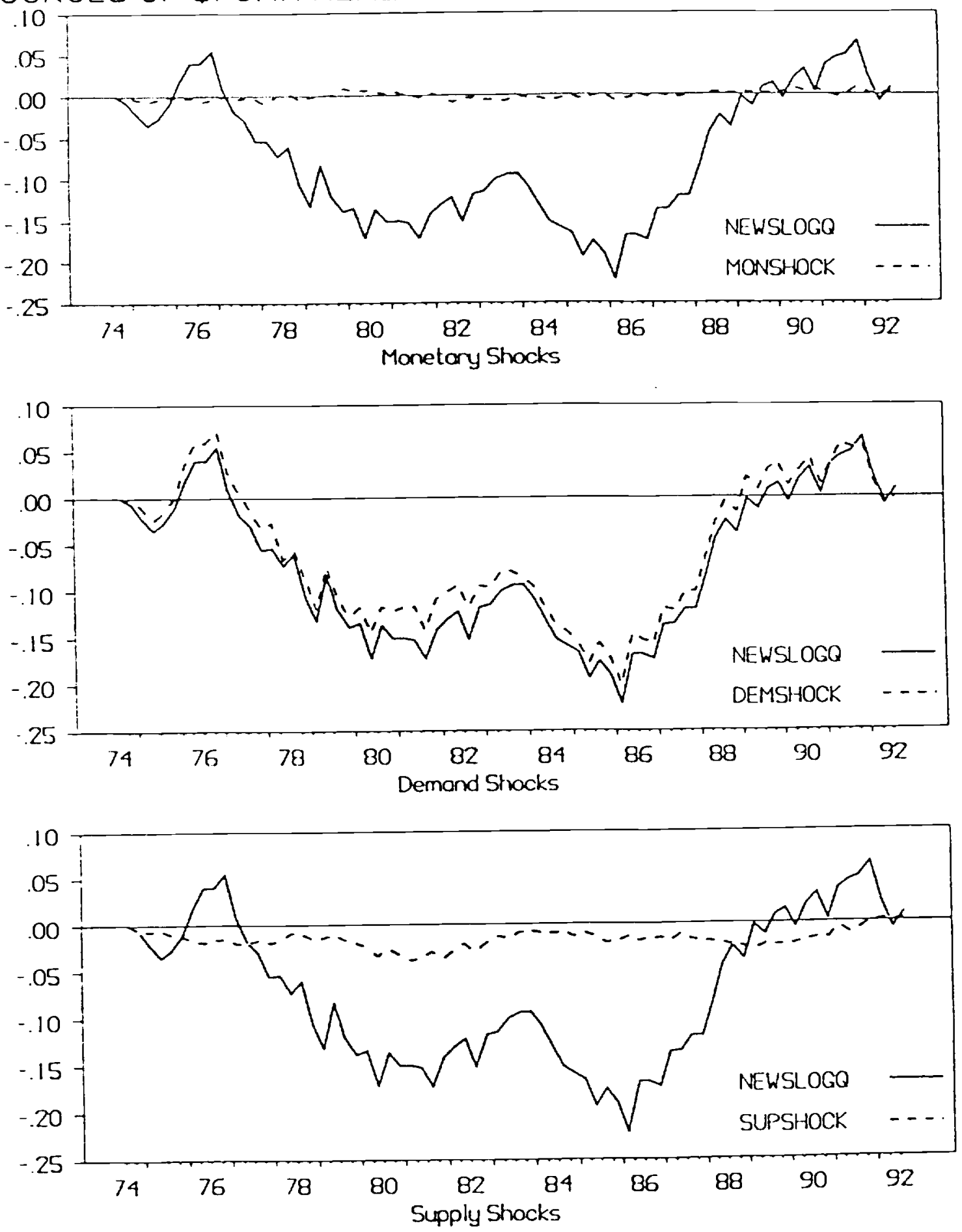

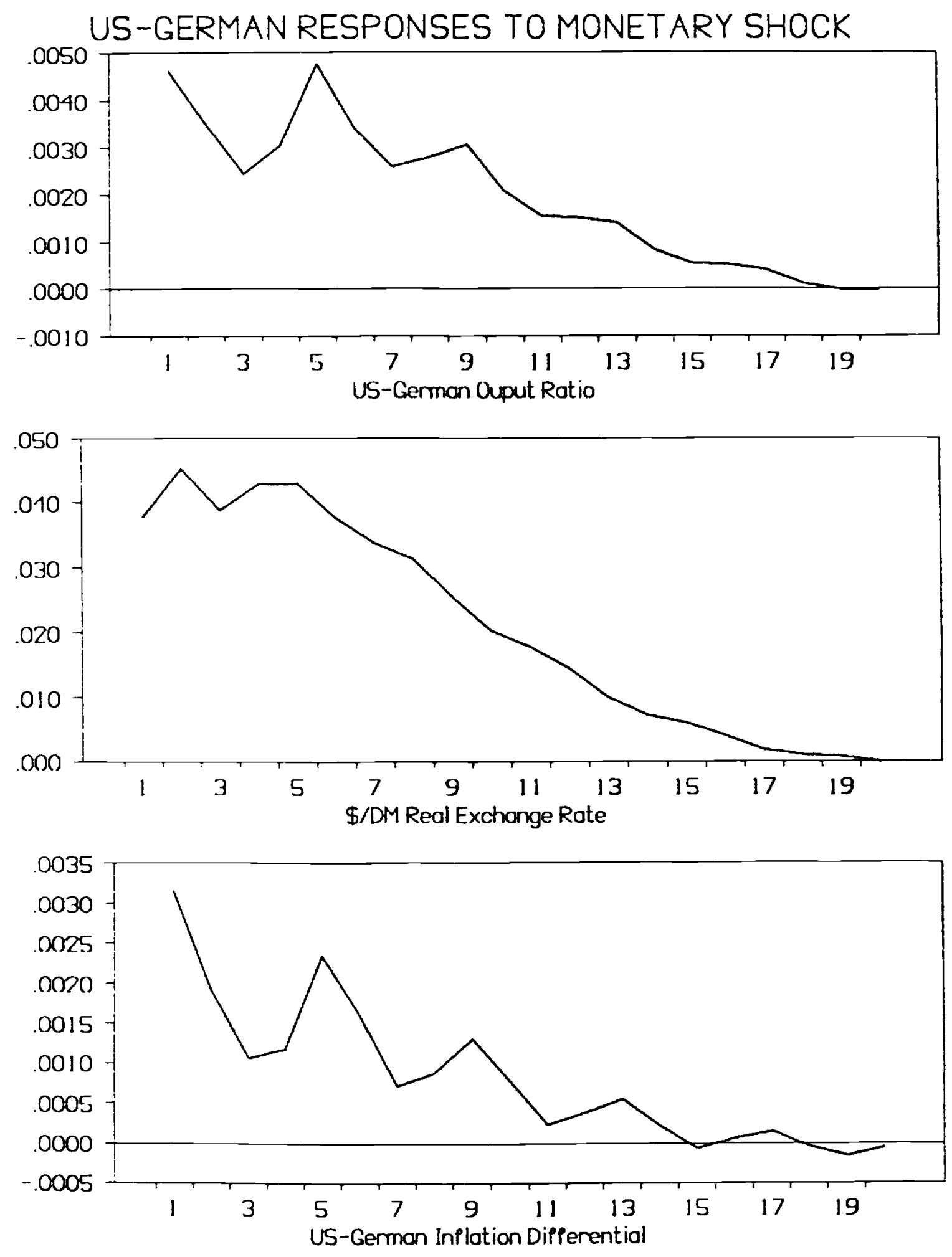
CILAR' 13B
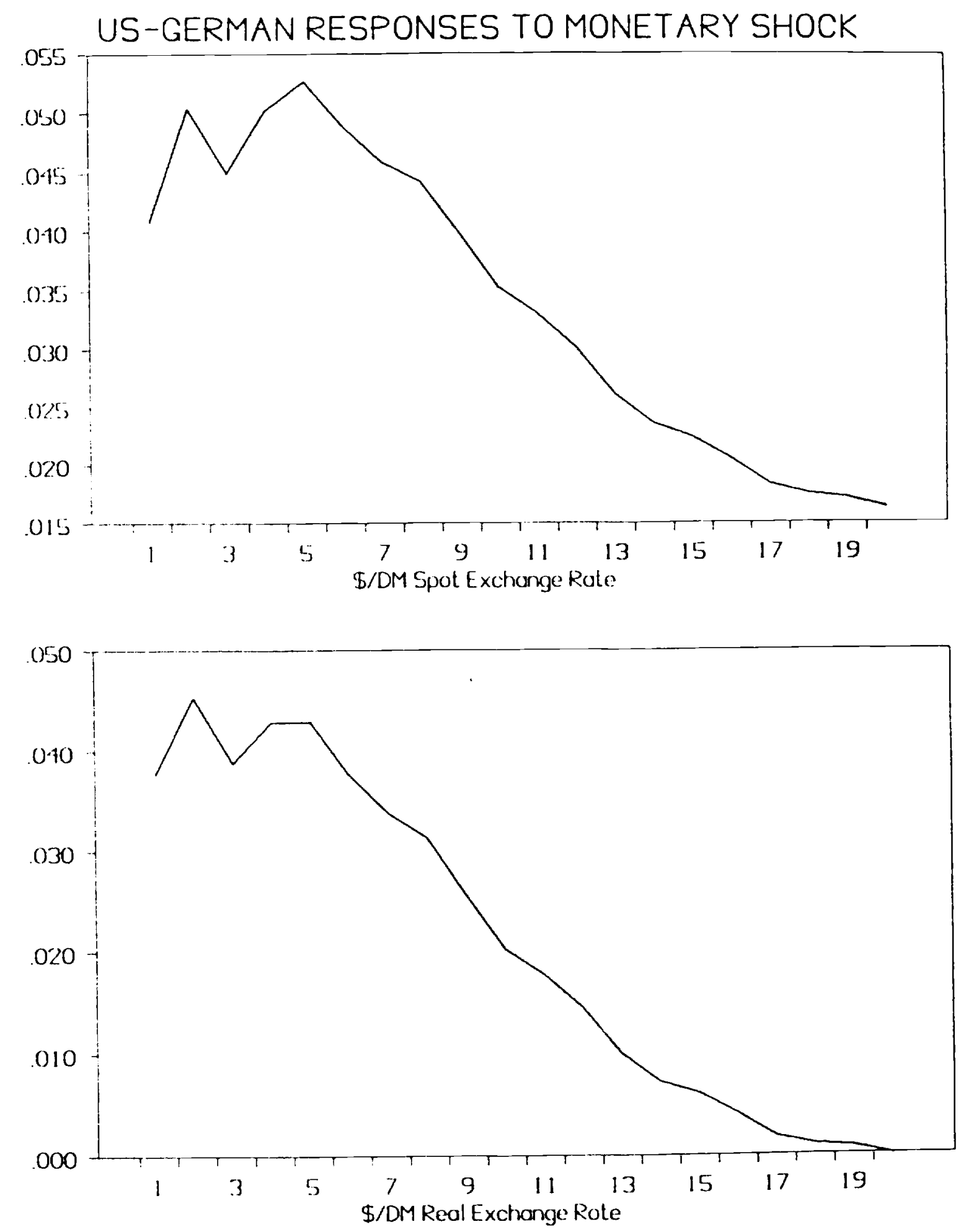

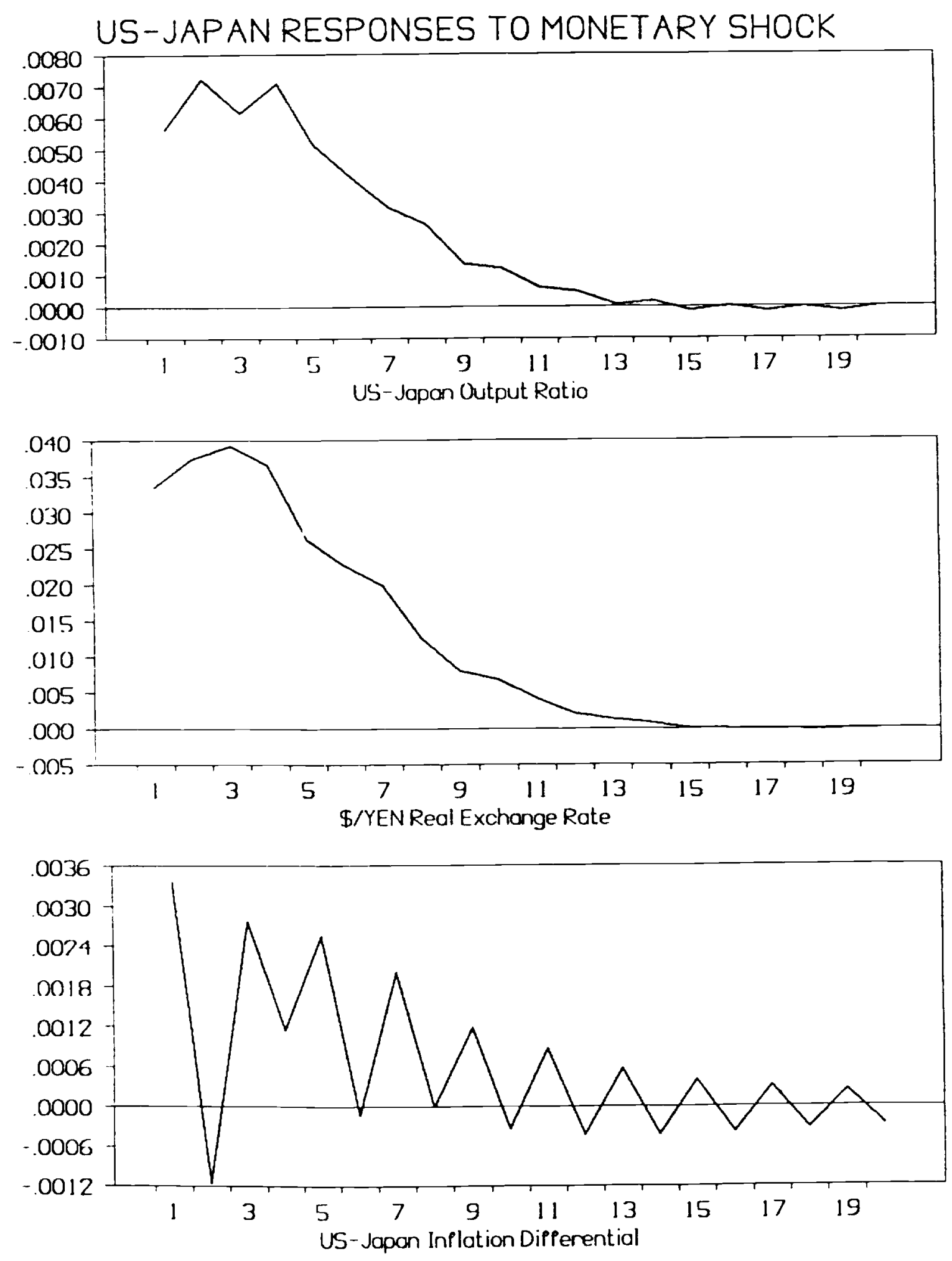
CHART 14B
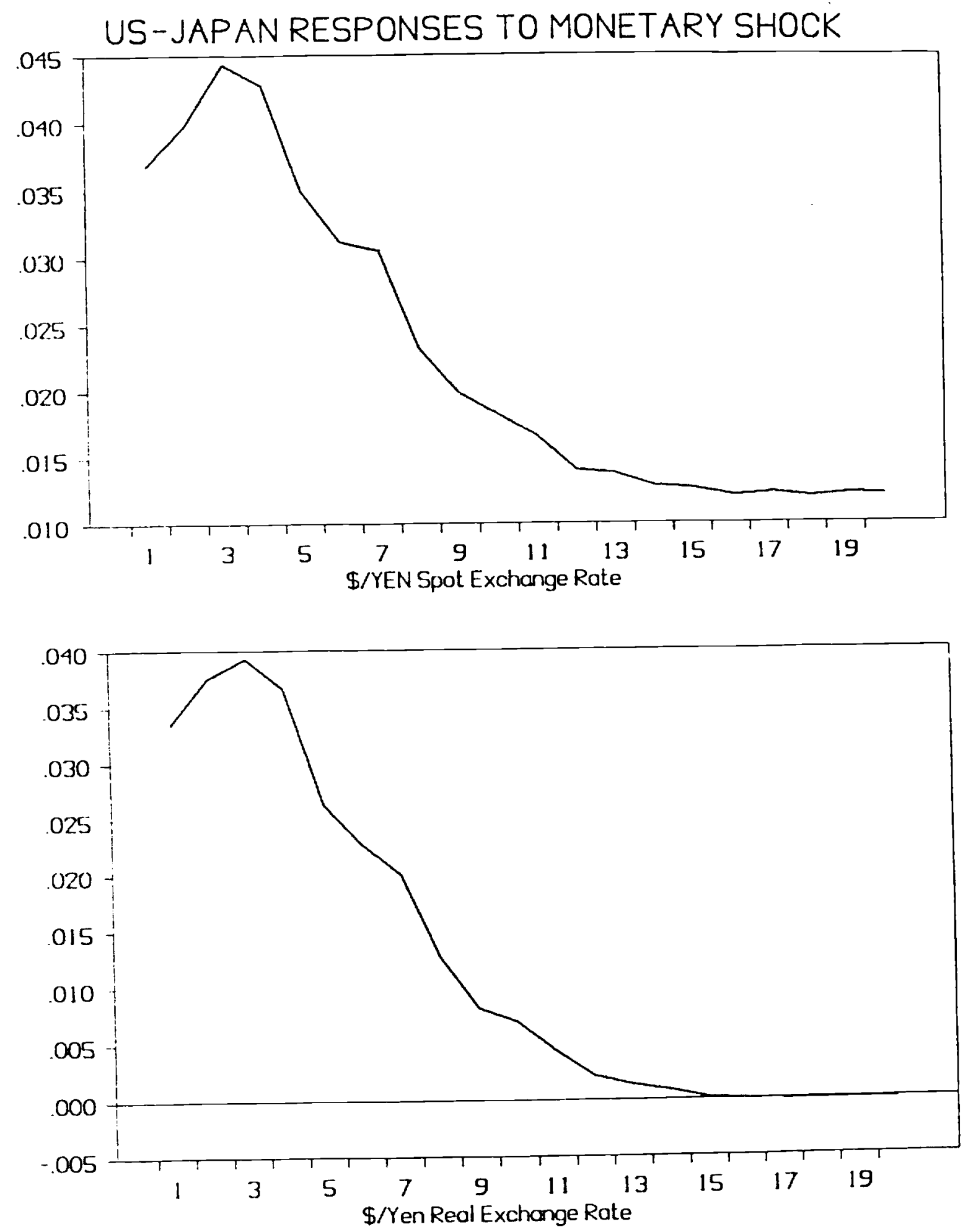